\title{
LA PRESENCIA DE LA MINORIA BAYONESA EN LA DINAMICA DEL COMERCIO FRANCO-ESPAÑOL DEL SIGLO XVIII ${ }^{1}$
}

\author{
por
}

\section{ANA MERCEDES AZCONA GUERRA}

Universidad de Bordeaux III

RESUMEN: Habida cuenta la importancia que el colectivo francés ejercio sobre las actividades mercantiles de las distintas áreas y meriados de la España del Setecientos se pasa a examinar el modo de penetración de los comerciantes originarios del Sudoeste francés (ésto es, vasco-bearneses), wno de los sectores más numerosos a mediados de siglo en el seno de la comunidad francesa operativa en España, a través del análisis de dos representativas casas comerciales bayonesas. Siguiendo el proceso de formación de redes comerciales basadas en el parentesio y el paisanaje y en sencillos sistemas de agencia se profundiza en el conocimiento de los sistemas de distribución mercantil a escala interregional (actuales provincias de Navarra, Soria y La Rioja). La comprensión del fenómeno no sería posible, no obstante, si no se integrase dentro de un análisis glabal del crecimiento comercial que desde mediados del siglo XVII conoció la ciudad-puerto de Bayona y su entorno, y de los vinculos que vertebró a través de la Navarra española en la Castilla oriental.

PALABRAS ClAVE: Siglo XVIII. Bayona. Navarra. Redes comerciales. Presencia mercantil francesa. Comercio interregional y transfronterizo.

1 Este trabajo se inscribe en un proyecto de investigación realizado durante nuestra estancia en el Centre d'Histoire des Espaces Atlantiques (Université de Bordeaux III) durante el curso 1994-95 bajo la dirección del profesor Paul Butel, gracias a una beca postdoctoral de Formación de Personal Investigador del programa bilateral MEC/MRE de becas en Francia FRA93. Agradecemos especialmente la amabilidad y facilidades brindadas para la consulta de los archivos de las Cámaras de Comercio e Industria de Bayona y Marsella.

Archivo Histórico Nacional (AHN)

Archivo General de Simancas (AGS)

Archivo General de Navarra (AGN)

Archivo Municipal de Pamplona (AMP)

Archivo Histórico de Protocolos Notariales de Pamplona (APNP)

Archivo Histórico de Protocolos Notariales de Tudela (APNT)

Archives Nationales de Patis (AN)

Archives de la Chambre de Commerce et Industrie de Bayonne-Pays Basque (ACCIB)

Archives de la Chambre de Commerce et Industrie de Marseille-Provence (ACCIM)

En lo sucesivo se citarán por las correspondientes siglas. 
ABSTRACT: Taking into account the importance of the French community on the commercial activities of the different areas and markets of seventeenth-century Spain, this study focuses on the pentration of these markers by the original traders from soutbuestern France (Basques and people from Bearn), one of the largest groups of French people operating in Spain in mid-century, through the analysis of two representative commercial firms from Bayonne. Beginning with the process whereby commercial inks based on family relationship and shrared rural background were formed, the article then looks more deeply at commerial distribution systems on the regional scale (in the current provinces of Navarra, Soria and La Rioja). Understanting this phenomenon would not be possible, bowever, without its being contextualized in a global analysis of the commercial growth of the port of Bayonne, and its binterland, at the western end of the Pyrenees, from the middle of the seventeenth century, and the links that connected in through Navarre with eastern castile.

KIYY WORDS: Eighteenth Century. Bayonne. Navarre. Commercial links. Frech Commercial Community. Interregional and Transfrontier trade.

Uno de los lugares comunes de la historiografía española alude a la influencia comercial y financiera que los extranjeros han tenido en la historia moderna de España. A modo de secuencia temporal se muestran los diversos grupos - genoveses, portugueses, flamencos, alemanes, irlandeses- que ocuparon un privilegiado e influyente lugar dentro de la economía española. Esta impronta extranjera, sin embargo, no es una realidad peculiar de España, los demás paises de nuestro entorno también han tenido comunidades mercantiles foráneas. Es más, el mundo del comercio es un mundo caracterizado por la movilidad espacial y el establecimiento e inserción de comunidades y minorías mercantiles de extranjeros alli donde ha habido perspectivas de negocio y beneficio. Baste recordat el carácter cosmopolita sobre el que se han conformado los principales centros portuarios europeos ${ }^{2}$. Pero, posiblemente, el rasgo más sobresaliente del panorama español durante el siglo XVIII sea el relativo control comercial --sobre los sistemas de aprovisionamiento de una naciente sociedad de consumo-, y la intermediación financiera, ejercidos por estos extranjeros, que poco a poco y con un desigual desarrollo regional fueron com-

$2 \mathrm{Al}$ respecto, véanse las Actas de la XXXI Settimana di Studio «F. Datini» de Prato, «Il ruolo economico delle minoranze in Europa, secc. XIII-XVII", abril 1999. JLANNIN, Pierre, «Les practiques commerciales des colonies marchandes étrangeres dans les ports français (XVIe -XVIIIe siècles)y: BuTE, P. y CuL,LN, L. M. (cds.), Actes du colloque franco-irlandais d'bistoire. Négoce et industrie en France et en Irlande aux XVTIIe at XIXe siecles, Paris 1980, pigs. 9-13; MkYTik, Jean «Les élites des villes portuaires à l'époque modemes: Mélanges offerts à Pierre Chaunu. La uie, La mort, la foi, Paris 1933, págs. 187-204. Por citar un ejemplo bien conocido por nosotros, durante el siglo XVIII, el comercio de entrepôt del principal puerto colonial francés, Burdeos, estuvo asegurado por comisionatios holandeses, hanseatas y prusianos que han dejado incluso huella en la actual nomenclatura de los barrios de la ciudad. Bute., Paul, Les négociants bordelais. L'Europe et les iles an XVIIle siëcle, Paris 1974; ibid., Les dynasties bordelaises de Colbert a Chaban, Paris 1991.

Hiqpania, LIX/3, núm. 203 (1999) 955-987 
pensados por el elemento nacional ${ }^{3}$. Desde mediados del seiscientos, el grupo francés ${ }^{4}$ había empezado a destacar. Hasta el punto de que una centuria después se hablará del siglo XVIII como el siglo de los franceses, llegando a multiplicar su número en la ciudad de Cádiz, principal enclave mercantil ${ }^{5}$ y en aquellos otros centros comerciales de relieve, como Madrid, Valencia, Alicante, Murcia, Cartagena, Málaga, Sevilla, La Coruña, Bilbao, Santander y San Sebastián. La historiografía francesa, desde los años sesenta e incluso antes - recordemos los trabajos de Girard y Sée mostró gran interés por la cuestión ${ }^{6}$. El pionero trabajo de Didier Ozanam ${ }^{7}$ sobre la colonia francesa de Cádiz matcó la pauta para futuras investigaciones, en las que primaría la óptica social y concretamente el análisis demográfico, como elemento vertebrador del estudio comercial. Esa tradición metodológica se ha mantenido viva hasta la actualidad ${ }^{8}$,

3 Especial interés en este sentido revela el caso de Cataluña donde se produce un retroceso de la inmigración francesa a partir de la guerra de Sucesión. En 1764 había censados sólo seis comerciantes franceses en Barcelona, dos en Reus y 10 en Tortosa, frente a los 23 que residian en Barcelona en 1715. ZYLBERßBERG, Michel, Une si douce domination. Les milieux d'affaires francais et l'Espagne, vers 1780-1808, Paris 1993, pág. 82.

4 Doníngute OkT7\%, Antonio, Los extranjeros en la vida española durante el siglo XVII y otros artículos, Sevilla 1996 (última edicjón), págs. 75-89. Esta presencia francesa llegó incluso a generat un clima de alarma general como puede comprobarse por la setie de medidas restrictivas adoptadas contra esta comunidad. Ś́nCHEz BELÍN, Juan Antonio y RAmos MEDINA, Ma Dolores, «La Junta de represalias de 1667 y los mezcaderes franceses en España): LoBo CABRERA, Manuel y SuÁrez Grimón, Vicente (eds.), III Reunión Científica de la Asociación española de Historia Moderna. El comercio en el Antiguo Régimen, Las Palmas de Gran Canaria 1994, 2 vol., págs. 245261.

5 Collado Villalta, Pedro, «El impacto americano en la Bahía: la inmigración extranjera en Cádiz, 1709-1819m: I Jornadas de Andalucia y América, Huelva 1981, vol. 1, págs. 49-73; GARCíA-Baquero, Antonio y Collado VILlaLTA, Pedro, «Les français à Cadiz au XVIIIe siècle: la colonie marchandes: VVAA, Les frangais en Espagne à l'époque moderne (XVIe-XVIIIe siècles), Paris 1990, págs. 173-197. En estos trabajos se acomete un tiguroso estudio de la colonia mercantil francesa desde la perspectiva de su organigrama socio-funcional, apuntando cómo el conocimiento de su talla, variaciones numéricas y composición a lo largo del siglo XVIII todavía puede considerarse escasamente satisfactorios.

6 Los estudios pioneros de Grkaw, Albert, «Une négotiation commerciale entre l'Espagne et la France en 1782m: Revue Historique 111 (1912) 292 y ss.; ibid., Le commerce francais à Séville et Cadix au temps des Habsbourg. Contribution à l'étude dts commerce étranger en Espagne aux XVIe et XVITe siècles, Paris 1932; ibid., «Les étrangers dans la vie économique de l'Espagne aux XVIe et XVIIe siècles»: Annales E.S.C. 5 (1933) 567-578; SÉE, Henri, «Notas sobre el comercio francés en Cádiz y particularmente sobre el comercio de las telas bretonas en el siglo XVIIIs: Anuario de Historia del Derecho Español 2 (1925) 179-196 y Du Boisrouvray, A., "Un exemple de l'esprit commetcial des français sous l'ancien régime. 'La nation française de Cadix au XVIIIme siècle's: Revue des questions bistoriques 2 (1936) 177-183.

7 (La colonie française de Cadix au XVIIIe siècle d'après un document inédit (1777)n: Mélanges de la Casa de Velarquez 4 (1968) 259-347, especialmente la pág. 279.

8 Seria prolijo citar todas las monografias que utilizando los censos y recuentos oficiales conservados en el Archivo Histórico Nacional, concretamente en la sección de Estado y de Consejos (para 1791) asi como los registros parroquiales, hospitalarios y las diversas fuentes fis- 
y las investigaciones de Zylberberg, insertas ahora en una dinámica política, han continuado mostrando las múltiples caras de esa «si douce domination»". Los historiadores españoles también han aludido por su parte, en las diversas monografías regionales dedicadas a los principales centros mercantiles peninsulares, a la activa presencia francesa, y más concretamente, a las complejas relaciones de parentesco y a esa especie de solidaridad regional trabada por las gentes del Sudoeste francés, uno de los grupos mayoritarios en el seno de esa comunidad. Dicho examen ha sido por lo general inscrito dentro de la problemática general del capitalismo comercial y de la búsqueda de una explicación de los orígenes del atraso industrial español ${ }^{10}$.

Junto a esos trabajos, que han resaltado la presencia de grupos de comerciantes y financieros franceses, preferentemente en marcos concretos del espacio andaluz, madrileño, levantino, cantábrico y aragonés, nuestro propósito en el presente estudio es subrayar la influencia comercial bayonesa, siguiendo algunas de las propuestas teóticas y metodológicas del network analysis ${ }^{11}$. La elección del microcosmos bayonés ha venido determinada por la constancia documental, de que fueron los originarios del Sudoeste francés, uno de los sectores más dinámicos dentro de las colonias mercantiles francesas que operaron en la España del setecientos. Para ello se han combinado dos tipos de aproximación: una económica, que aborda el estudio e inserción de la red bayonesa en las distintas áreas y mercados que articularon el espacio comercial español, preferentemente del interior, y otra social, que incide en el relevante papel que jugaron los vínculos personales (parentesco, paisanaje, amistad, patronazgo, religiosos) en la confrguración de las empresas y redes mercantiles durante la época preindustrial. Primeramente, se harán algunas reflexiones de carácter general sobre el papel de la villa-puerto de Bayona dentro de la dinámica de las relaciones comerciales franco-españolas, dejando de lado, por ser más conocida, la política comercial sobre el tema ${ }^{12}$. Después, plasmaremos esas relaciones

cales han logrado reconstruir las colonias francesas repartidas por toda la geografia española durante esa centuria. El trabajo pionero y clásico en este sentido sigue siendo el de $\mathrm{N}_{A D A}$, Jordi y GIRALT, E., La population catalane de 1553 à 1717: linmigration frangaise et les autres facteurs de son développement, Paris 1960. Dos recientes síntesis sobre la cuestión: AMALRIC, Jean-Pierre, «Les migrations françaises en Espagne à l'époque moderne (XVIe-XVIIIe siècles)». I Conferencia europea de la Comisión Internacional de Demografia bistónica. Migraciones internas y medium-distance en Europa 1500-1900, Santjago de Compostela 1993, págs. 327-345 y SNLAS AUSIENS, J.A.: «Les français en Espagne dans la deuxième moitié du XVIIIe sièclen: VV.AA., Les frangats en Espagne à l'ppaque moderne (XVle-XVMIe sièctes), Paris 1990, págs. 155-171. Este ultimo autor señala que en 1791 de los 4.300 franceses censados en España, 803 se dedicaban a las actividades mercantiles.

9 ZYL.lsERlilerG, Michel, op. cit.

10 Un trabajo modélico en este sentido, FranCl BLNAVLNT, Ricardo, El capital comercial valenciano ent el siglo XVTI, Valencia 1989.

11 Un planteamiento general, aunque para distinto marco cronológico, Pło Rusz, Juan (Las élites de la España liberal: clases y redes en la definición del espacio social (1808-1931)»: Historia social 21 (1995) 47-75.

12 Además de la obra clásica de RAMI3ERT, Gaston, «La France et la politique commerciale de l'Espagne au XVIIIe sièclen: Revue d'Histoire Moderne et Contemporaine 6 (1959) 271-288. Otros

H-lippania, L.JX/3, núm. 203 (1999) 955-987 
a través de la implicación bayonesa en la región del Alto Ebro, la más próxima a la frontera pirenaica occidental, incidiendo en los intercambios de carácter intertegional y transfronterizo efectuados en esa zona. Todo ello se concretará a través del análisis de la organización de dos casas comerciales bayonesas, la de los Barrau y Daguerre, representativas del modo de operar de los comerciantes franceses en ese espacio, y a través de él, en otras áreas peninsulares.

\section{BAYONA, UNA VILLA DE FRONTERA}

Ubicada en el extremo meridional de la fachada atlántica del Sudoeste francés, en el llamado golfo de Gascuña, la villa de Bayona conoció desde mediados del siglo XVII un gran desarrollo comercial, paralelo al crecimiento de la presencia francesa en las pequeñas Antillas. El carácter fronterizo de esta villa otorgó a sus comerciantes un destacado protagonismo en las relaciones comerciales hispano-francesas. Como señala Pontet-Fourmigué, la vocación española de este puerto ${ }^{13}$, distante tan sólo cuarenta kilómetros de la frontera, es elemento clave para entender el relevante papel que una villa de reducidas dimensiones jugó -sorprendentemente-, en los intercambios comerciales y financieros entre los dos países. Bayona fue junto a Marsella la plaza francesa que concentró durante el siglo XVIII un mayor volumen de plata española convertible en moneda de curso regular ${ }^{14}$. Además de puerto fluvial, Bayona reunía la condición de ser nudo interregional de comunicaciones terrestres, vertebrando con su arriére-pays una compleja malla, articulada en torno a tres rutas principales: la que se dirigia a Castilla a través de Navarra y/o el País Vasco; la que atravesando las Landas enlazaba con el puerto colonial de Burdeos y, por últi-

dos autores que han abordado ultimamente esta cuestión han sido TLDDE DE LORCA, Pedro, "Politica financiera y política comercial en el reinado de Carlos III": Actas del Congreso Internacional sobre 'Carlos III y la Ilustración', Madrid 1989, págs. 139-217 y STEIN, Stanley J., "Un raudaI de oro y plata que corría sin cesar de España a Francia': Política mercantil española y el comercio con Francia en la época de Carlos IYI»: ibidem, págs. 219-280.

13 PONTET-Folrmigul' Josette, «Bayonne, port moyen à l'époque moderne»; Coljun, Michèle (dir), Ville et pont, XVIIlè-XXè siècles, Paris 1994, págs. 25-39.

14 DermignY, Louis, "Circuits de l'argent et milieux d'affaires au XVIIIe siècle»: Revue Historique 212 (1954) 239-278 e ibid, "Une carte monétaire de la France à la fin de l'ancien régimes: Annales ESC 10 (1955) 489-490. A través de los pasos del Pirineo occidental se enviaban grandes cantidades de plata a Bayona y desde alli se distribuían, principalmente a Marsella, Burdeos, Limoges y Paris. Como indicó el fermier général de Bayona en 1788, sea a través de los pasos de Behovia y San Juan de Luz, sea por Ibardin y Olhette, o por Ainhoa y San Juan de Pie de Puerto la plata siempre converge en Bayona. También desde los puertos pesqueros vascos se enviaban ingentes cantidades de plata a Bayona. AN F 12/ 1889. No en vano, entre 1782 y 1789 correspondió a Bayona el $21 \%$ de la plata acuñada en Francia, a Pau el $14 \%$ y a Toulouse el $12 \%$. Sin embargo, a partir de 1788 , como consecuencia de la política comercial española se redujo en una quinta parte la salida de plata por la frontera del Pirineo occidental, pasando de casi cuatro millones de piastras en 1787 a 800.000, en 1788 .

Hitamia, L.IX/3, núm 203 (1999) 955-987 
mo, la que comunicaba con la ciudad de Toulouse, centro director del Medioda francés, y desde allí se dirigía al puerto mediterráneo de Marsella, una de las principales puertas de entrada del comercio francés en la Carrera de Indias.

Las posibilidades comerciales de esta estratégica situación venían siendo ampliamente utilizadas desde la edad media por los hombres de negocios bayoneses. Baste recordar el intenso tráfico de cabotaje existente entre Bayona y los puertos del Norte peninsulat, al compás del desarrollo mercantil y urbano que animó el camino de Santiago ${ }^{15}$. Para mediados del siglo XVII, los comerciantes bayoneses estaban perfectamente integrados en los circuitos del intercambio europeo, superando la marginación y/o el orillamiento a que les abocaba su situación periférica y excéntrica dentro del espacio comercial francés ${ }^{16}$. Las firmas comerciales bayonesas se habían orientado, como el resto del comercio francés, hacia nuevos mercados y espacios - el Mar del Norte, el Báltico, la Península Ibérica, el Caribe e incluso, el llamado Levante-_, configurando redes mercantiles cada vez más complejas y mejor articuladas. A escala regional, también desde mediados del seiscientos, Bayona había afianzado su primacía dentro del subsistema portuario vasco (Guipúzcoa y Labourde ${ }^{17}$ ); primacía sólo contrapesada por los ugigantes" portuarios de Burdeos y Bilbao. La rivalidad con el vecino puerto de San Sebastián, por el control de las redes de exportación del tráfico lanar de la región del Alto Ebro y su área circundante, había quedado saldada a mediados del siglo XVII, a favor del puerto bayonés, aprovechando la «dureza» de la política arancelaria española derivada del conflicto hispano-holandés ${ }^{18}$. Aunque unos años después, en 1726, la ciudad donostiarra, por una confluencia de voluntad política y habilidad de su grupo mercantil consiguió, con la creación de la Compañía de Caracas, recuperar una parte del protagonismo que había tenido en el siglo XVI, gracias a la exportación lanar, ahora su campo de actuación ya no sería el Norte europeo sino el Caribe. Bayona, por su parte, lo mismo que la vecina San Sebastián, también se orientó hacia el tráfico caribeño y recibió igualmente el respaldo estatal: en 1717 , se confirmaron sus antiguos privilegios fiscales; en 1726, se constituyó la Cámata de comercio -institución corporativa cuyo principal cometido era defender los intereses de su clase mercantil-; y ya, a finales de la centuria, en 1784, el Estado la dotó, para paliar su declive comercial, de la condición de puerto franco, lo que motivó un indudable crecimiento del tráfico marítimo y terrestre.

\footnotetext{
15 GOYHENECHE, Eukeni, Bayonne et la région bayonnaise au XVe siècle. Études d'bistoire économique et sociale, Vitoria 1990.

16 LEon, Pierre (ed.), Colloque National de l'Association frangaise des Historiens Economistes, 'Aires et Structures du commerce frangais au XV TIIe siècle', Patis 1973.

17 Los otros puertos de San Juan de Luz, Guetary, Hendaya, cap Bretón, Deva o Motrico actuaban de mera constelación con una restringida función pesquera y corsatia.

18 La obra clásica sobre esta cuestión sigue siendo la de Domingufž Orirz, Antonio: "Guerra económica y comercio extranjero en el reinado de Felipe IV»: Hispania 89 (1963), págs. 74-90. La Cámata de Comercio de Bayona estimaba que en torno al $20 \%$ de las lanas españolas se exportaban por su ciudad.
}

Hichaniu, LIX/3, núm. 203 (1999) 955-987 


\section{BAYONA, DENTRO DE LA DINAMICA EXPANSIVA DEL COMERCIO FRANCÉS EN ESPAÑA Y SU IMPERUO COLONLAL}

Bayona participa de lo que Poussou define desde 1680 como l'âge atlantique de l'économie française o el gran siglo del comercio maríimo francés to. Una actividad coinercial estrechamente ligada a los intercambios con la Península Tbérica y su Imperio colonial, no en vano, Bayona era llamada la puerta occidental de Espana, por ser uno de los principales centros del comercio terrestre franco-español. Es sabido que los intercambios mercantiles de España con sus extensas posesiones americanas se adecuaron desde el principio a una concepción politica, la del monopolio, que obligó a centralizar primero en la plaza de Sevilla, y después, desde 1717, en Cádiz, los intercambios mercantiles entre Europa y la América española. Desde finales del siglo XVI, ante la incapacidad española para satisfacer las enormes necesidades de su dilatado imperio y absorber en su mercado la totalidad de la producción americana, surgieron y se asentaron con carácter estructural una serie de mecanismos - las diversas formas de fraude y contrabando- que vulneraban el sistema del monopolio gaditano. Ya para entonces, numerosas comunidades de comerciantes y financieros no españoles se habian establecido en Sevilla, para traficar con las Indias españolas. Esas comunidades foráneas en colaboración con los locales - Ios famosos cargadores de Indias y encomenderos- fueron hilvanando un complejo entramado de intereses y subterfugios, que les permitió vulnerar y/o acomodarse a la legislación comercial española de la Carrera de Indias. Aunque, desde mediados del siglo XVII, habian empezado a cobrar importancia los intercambios comerciales directos, que los distintos países europeos realizaban con la América hispana, todavía un siglo después, al margen de esas nuevas fórmulas y rutas -como la que condujo a los maluinos a las costas del Perú ${ }^{20}$-, seguían operando las colonias de extranjeros, principalmente franceses ${ }^{21}$, y las de los españoles no andaluces, asentados en el puerto gaditano y en el resto de los enclaves peninsulares, que tenían relevancia mercantil y financiera, y progresivamente serían habilitados para el comercio americano.

La ciudad de Bayona, aunque geográficamente alejada de la dinámica fachada andaluza, supo a semejanza de otros puertos del Norte español, participar desde el siglo XVII activamente en el negocio americano, gracias a la vinculación de sus comerciantes con la red de agentes franceses - corresponsales,

19 Poussou, Jean-Pierre, «L'âge atìntique de l'économie française (vers 1680-vers 1780)»: Linformation Historique 59, 1 (1996) 21-34.

20 Malamud RIkıes, Carlos, «El comercio colonial del siglo XVIII visto como suma del comercio vía Andalucía y del comercio directo europeom: Revista de Historia económica 1 (1983) 307-321.

21 Este asentamiento francés habia empezado a ser significativo a mediados del siglo XVII. Coll.ADO VILLALTA, Pedro: «En torno a los origenes del monopolio comercial gaditano: mercaderes extranjeros y cambio económico del átea sevillana a la bahía de Cádiz en la segunda mitad del siglo XVII: Actas de los II Coloquios de Historia de Andalucia. Andalucia Moderna, Córdoba 1983, tomo 1, págs. 603-615. 
consignatarios, comisionados, factores y demás intermediarios-instalados en Cádiz. A través de ellos, se financió una buena parte del comercio americano mediante los préstamos à la grosse y los seguros marítimos, como ha mostrado Bernal en sus investigaciones, «llegándose a convertir desde el último tercio del siglo XVII, estos franceses, en los principales acreedotes de la Carrera de Indias» ${ }^{22}$. De la importancia de la presencia mercantil francesa en la plaza gaditana queda constancia en una muy abundante bibliografía. Pero lo que a nuestro propósito interesa señalar es el porcentaje que suponían dentro de los mismos los originarios del Sudoeste francés. A la altura de 1777, el 42,8\% de los comerciantes franceses de la bahía eran -como muestra Didier Ozanam-de origen vasco-bearnés y de ellos, concretamente el $20,2 \%$, bayoneses ${ }^{23}$. Otro tanto sucedía, aunque en menor medida, en las ciudades de Sevilla, Málaga ${ }^{24}$, Jaén y Ubeda. La implicación bayonesa en el comercio español no se limitó a Cádiz, la proximidad de la villa del Adour a los puertos cantábricos explica el establecimiento de un elevado número de agentes en esos enclaves. Según apunta Miard 26, Bilbao tenía en 1763, 32 comerciantes franceses, de los cuales algo más del $50 \%$ procedian del Sudoeste francés ${ }^{27}$. San Sebastián, por su parte, disponía de un influyente grupo de 22 comerciantes en 1764, siendo la mayoría también naturales del País Vasco-francés. Algo similar sucedía en el puerto de La Coruña ${ }^{28}$,

$22 \mathrm{El} 46 \%$ de las utilidades estimadas del comercio con América en 1753 y el $42,5 \%$ de las del año 1762 correspondieron a los intermediarios franceses. Sobre esta participación extranjera desde los mismos orígenes de la Carrera, véase BERNN., Antonio-Mguel, La financiación de la Carrera de Indias. Dinero y crédito en el comercio colonial español con América (1492-1824), Madrid 1992, págs. 450-457; ibid, «Los costes y beneficios del Imperio hispánicon: ponencia presentada al VI Congreso de La Asociación de Histona Econtomica, 15-17 de septiembre de 1997 (actas mecanografradas), págs. 81-87.

23 OzANAM, Didier, op. cit., pág. 279. En 1777, la región vasco-bearnesa se situó a la cabeza en cuanto a número de casas de comercio, asociados y negociantes, mientras que en 1714 habían sido las regiones de Provenza y Bretaña las que habian marcado la pauta.

24 VIL.AR, Begoña, Los extranjeros en Málaga en el siglo XVIII, Córdoba, 1982, pág. 54. En 1765 , los de origen bearnés suponían casi el $78 \%$ de los inmigrantes de origen pitenaico y eran los que se dedicaban con mayor exclusividad a las actividades mercantiles.

25 CoronAs 'T'EJADA, $L$, «La inmigración francesa en las ciudades de Jaén y Ubeda en la segunda mitad del siglo XVIII, en Actas de los Segundos Coloquios de Historia Moderna de Andalucia, Córdoba 1983, tomo I, pág. 35-54. En estas ciudades existía una presencia de inmigrantes procedentes de todo el Pirineo.

26. MIARD, Louis, Présences français en Espagne à Bilbao et autour de cette ville dans la séconde moitié du XV III siècle (1750-1805) (ejemplar mecanografiado), Thèse d'État, Université de Haute Bretagne, Rennes 1987.

27 ZABAL URIARTE, Aingeru, Mundo urbano y actividad mercantil. Bilbao, 1700-1810, Bilbao 1994, págs. 479 y 370 . La mayoría de los comerciantes franceses eran naturales de Bayona y de las localidades vecinas. A finales de siglo había 13 casas comerciales extranjeras. En 1784, con la concesión de la franquicia a Bayona, este puerto llegó a acaparar la mayor parte del comercio francés de Bilbao.

28 Alonso Atvárez, Luis, Comercio colonial y crisis del Antiguo Régimen, 1778-1818, La Coruกิa 1986 .

Hiphania, LIX/3, núm. 203 (1999) 955-987 
que contaba con una centena de comerciantes franceses y en la ciudad de Santander. Asimismo, las regiones próximas a la frontera pirenaica ${ }^{20}$ habían visto crecer, desde mediados del siglo XVII ${ }^{31}$, el número de franceses, acentuando lo que era un tradicional fenómeno migratorio. Por poner varios ejemplos, en Zaragoza ${ }^{31}$ había en 1642,45 mercaderes franceses y un siglo después, en 1765,30 comerciantes, de los cuales, 18 eran originarios del Sudoeste francés. La ciudad de Pamplona ${ }^{32}$, por su parte, registraba en 1764 , trece comerciantes procedentes del Sudoeste francés, diez años después su número se había elevado a 22 y, en 1784, contaba con 32 comerciantes oriundos de esa zona de Francia. Algo similar cabría decir de las regiones y ciudades del Levante español: en Alicante ${ }^{33}$ aparecen registrados en 1742, 26 comerciantes franceses, en Murcia ${ }^{34}$, concretamente, 37 comerciantes de origen bearnés, lo que suponía algo más del $60 \%$ del total de comerciantes franceses radicados en la tegión y, en Valencia, los ejemplos recogidos por Poitrineau y Franch Benavent muestran así mismo el origen vasco-bearnés de bastantes de ellos. Finalmente, la villa de Madrid concentró, por su condición de capital política y de gran centro de consumo, un elevado número de inmigrantes franceses ${ }^{35}$ empleados en distintas actividades mercantiles, de los cuales, a mediados de siglo, en torno a la mitad eran ori-

29 FORNE், joseph, «Echanges pyréneéns: esquisse d'une problématique de l'espace sous l'ancien régimen: VVAA, Les Françats en Espaghe á l'époque moderne (XVIe-XVIIIe siècles), ToulouseLe Mirail 1990, págs. 241-258.

30 LANGÉ, Christine, La inmigración francesa en Aragón (sigho XVI y primera mitad del XVII), Zaragoza 1993.

31 La mayoría de los cuales procedían de Bearne y Gascuña. Gómez Zorinquino, José Ignacio, La burguesía mercantil en el Aragón de los siglos XVTy XVII, Zaragoza 1987, págs. 223-224 y SALAS AUSENS, J. A., "La inmigración francesa en Aragón en la edad modernav: Estudios (1985/86) 51-77.

32 Salas Ausens, José Antonio, «Extranjeros en Navarra en la segunda mitad del siglo XVIIIs: Actas del I Congreso de Historia de Navarra de los siglos XVIII, XIX y XX, Pamplona 1986, págs. 67-78; AzCona Guerra, A.M., Comerio y comerciantes en la Navarra del siglo XVIII, Pamplona 1996, capitulo VI.

33 GIMENEz, Enrique, Alicante en el siglo XVIII. Economia de una ciudad portuaria en el Antiguo Régimen, Valencia 1981, pág. 67.

34 Pérez Hervás, Jesús y Pérez Ortiz, Antonio Luis, «Estructura familiar y condición social de la población francesa en Murcia (siglo XVIII)w: Francisco Cincón y Llorenç Frerer (eds.), Actas del Congreso Internacional. Historia de la familia. Una nueva perspectiva sobre la Sociedad Europea, Familia, Casa y Trabajo, Murcia 1994, págs. 297-313 y Pírez PICAZO, Maria Teresa y LEMEUNIER, Guy, El proceso de modernización de la región murciana (siglos XVI-XIX), Murcia 1984, págs. 193- 201.

35 OzAn凡 , Didier, «Les français à Madrid dans la deuxième moitté du XVIIIe siècle»: Santos Madrazo y Virgilio Pinto (eds.), Actas del Coloquio Madrid en la época moderna. Espacio, sociedad y cultura, Madrid 1991, págs. 177-199 y ZYLBERbERG, Micheil, «Un centre financier 'périphérique': Madrid dans la seconde moitié du XVIIJe siècles: Revue Historique 249.2 (1983) 265309. En 1764, veinte de los 43 comerciantes y financieros franceses censados en la capital procedian de la región vasco-bearnesa. Unos años antes, en 1750, también los más importantes, como señala Ozanam, eran originatios de esta zona, op. cit., pág. 179. 
ginarios del Sudoeste francés. La historiografía francesa explica el atractivo que las regiones de Aragón, Navarra y el País Vasco español ejercieron sobre estas áreas pirenaicas, tradicionales tierras de emigración, argumentando razones de proximidad geográfica, de vínculos históricos, así como el peso de la tradición y la costumbre. Lo mismo que en los desplazamientos de largo recorrido, estos traslados de población se fundamentaban en vínculos familiares, de parentes$\mathrm{co}$, amistad y paisanaje, convertidos asi en los eslabones que mantenían el dinamismo de la red migratoria.

\section{UN PUERTO DE ENTREPÔT}

Los comerciantes bayoneses se emplearon enteramente en el comercio de entrepôt. Captaban, almacenaban y posteriormente redistribuían mercancías importadas de otros puertos, principalmente franceses, sin establecer apenas líneas de tráfico directo con el espacio americano o con el Norte europeo ${ }^{36}, y$ sin implicarse tampoco en la comercialización de la producción generada por su mediocre arriére-pays. ${ }^{37}$ Sólo entre un 2 y $3 \%$ de los navíos que salieron del puerto de Bayona durante la segunda mitad del siglo XVIII tuvieron como destino la América colonial. Sin embargo, por la proximidad de Bayona a los enclaves portuarios de Burdeos, por un lado, y de San Sebastián-Pasajes, por otro, se multiplicarán las posibilidades de participación indirecta de los hombres de negocios bayoneses en el tráfico colonial hispano-francés, aprovechando los intermediarios vasco-franceses, bearneses y gascones, radicados en esos puertos. En el período comprendido entre 1733 y 1790 se armaron en Bayona tan sólo 38 navíos, frente a los 375 y 155 de los puertos de Burdeos y Nantes, en cambio el comercio de cabotaje tepresentó por esos mismos años, entre 1730 y 1763 , el $80 \%$ del tráfico total del puerto bayonés, siendo los enclaves portuarios españoles del Norte español los principales interlocutores de ese tráfico, lo que confirma la importancia de la función intermediaria desempeñada por los bayoneses dentro del comercio hispano-francés.

Estos comerciantes ordenaban a sus comisionados y/o corresponsales en dichos puertos la compra de coloniales y la inversión de capitales en los armamentos y expediciones allí preparados. Así, en 1746, el comerciante bayonés Pierte Jautard, residente en San Sebastián, fue comisionado por su compatriota Dominique Labat ${ }^{38}$ para la venta en el puerto de Veracruz de nueve fardos de

\footnotetext{
36 Entre 1758 y 1780 , la mitad de los navios que entraron y salieron del puerto de Bayona tuvieron su origen en un puerto francés. Ponic'!-FourmIGuE, Josette, Bayonne un destin de ville moyenne à l'épogue Moderne, Biarritz 1990.

37 Esta es una de las principales diferencias con el puerto de Burdeos, salida natural de un próspero hinterland. BuTCL, Paul, Les négociants bordelais. L'Earope et les îtes au XVIII siècle, Paris 1974.

38 Las mercancías fueron cargadas en el navio español «El Extravagante» amarrado en el puerto de Pasajes, propiedad del armador donostiarra Juan Ignacio Otaegui. Contrato à la grosse aventure registrado en la sede del Aimirantazgo de Bayona. Una copin en ACCIM-P, fonds Roux, LIX 148.

Hipunta, LIX/3, núm. 203 (1999) 955-987
} 
mercancías valotadas en 26.000 libras. También tecibió del mismo Labat un préstamo de 9.008 libras y 10 sueldos para invertirlo en dicho armamento, del que esperaba obtener una rentabilidad del $115 \%$. Otros comerciantes bayoneses fueton atraídos igualmente por empresas ultramarinas. Conocemos varios contratos à la grosse firmados sobre esta misma expedición, que muestra una vez más la implicación bayonesa en el tráfico colonial guipuzcoano.

El Catibe y la América española estaban presentes igualmente en el negocio bayonés, que hacía un doble juego, participando simultáneamente del tráfico colonial español y francés. Los comerciantes bayoneses, expertos conocedores de los circuitos que seguían los productos coloniales de alto valor añadido - cochinilla, palo de campeche, algodón, cacao, azúcar- encargaban a sus corresponsales en los centros portuarios españoles - La Coruña, Reinosa, Cádiz o San Sebastián-, donde arribaban con regular perioticidad barcos cargados con esos productos, la compra de alguna partida, ordenando postetiormente su transporte hasta Bayona, donde personalmente se encargaban de su redistribución. En 1748, el comerciante bayonés Lopes Fonseca pidió a su amigo y corresponsal gaditano la firma Verduc, Vincent y Cia una remesa de 52 zurrones de cochinilla, para su venta en el Medioda francés. La carga debía enviarse al puerto de Marsella, a la firma consignataria de los Roux ${ }^{39}$.

Una de las máximas preocupaciones de estos comerciantes era conseguir unos bajos costes de transacción, haciendo detenidos cálculos sobre las tasas y los medios de transporte más económicos. Generalmente, allegaban los productos coloniales hasta Bayona, haciendo amplio uso del tráfico de cabotaje y luego los redistribuian en el Medioda francés, combinando el tráfico fluvial (a través del Canal del Midi) con el terrestre. Otras veces, desde los puertos cantábricos ordenaban a sus agentes, allí destacados, la introducción de mercancías en el mercado castellano, siguiendo las rutas carreteriles de la zona, evitando de ese modo el rodeo de Bayona. Pero con mayor frecuencia, eran los pasos del Pirineo occidental, por donde se enviaba el mayor volumen de productos coloniales, ya manufacturados, a la región navarro-aragonesa y de la Castilla oriental, e incluso, si la coyuntura era favorable, hasta el gran centro de consumo de Madrid. Es dificil, de todas formas, cuantificar el volumen de coloniales que entraron en el mercado español por esa vía o a través de los puertos exentos vascos, y resulta por tanto complicado medir el grado de penetración de la red bayonesa. También lo es distinguir la procedencia exacta de los coloniales comercializados por los bayoneses, buena parte de los cuales llegaban vía Amsterdam, gracias a los lazos existentes entre las comunidades judias bayonesa y holandesa. Los registros de las aduanas del cordón del Ebro, de las aduanillas vascas, de las tablas de Navarra y las fermes francesas, así como las estadísticas portuarias, las minutas notariales, la correspondencia mercantil de algunas firmas y los informes oficiales, motivados por el tráfico de contrabando, aportan cierta información al respecto, como tendremos ocasión de comprobar al exa-

39) ACCIM-P, LIX 148.

Ihigsoniu, LIX/3, núm. 203 (1999) 955-1987 
minar el funcionamiento de la penetración bayonesa en el mercado interior del valle medio del Ebro.

Además de la participación indirecta en el comercio americano, los comerciantes bayoneses mantuvieron estrechas conexiones con el Norte Europeo, pero sobre todo con el espacio fabril francés, como medio de garantizar su aprovisionamiento de manufacturas. Importando toda clase de textiles, manufacturas, pertrechos navales y diversas clases de productos alimenticios, como el demandado bacalao, de los puertos entrepôt de Stettin, Altona, Hamburgo, Amsterdam y Londres ${ }^{40}$, gracias a la correspondencia que mantuvieron con las principales firmas alli radicadas, buena parte de las cuales estaban emparentadas con la comunidad judía de Bayona ${ }^{41}$. Pero sus preferencias iban dirigidas a los nucleos textiles franceses, lo que dice mucho en su favor sobre el control que ejercieron sobre este espacio fabril. Las mercancias posteriormente eran canalizadas a los diversos mercados regionales españoles, preferentemente los del Alto Ebro, la cabecera del Duero, el País Vasco, Madrid, la Baja Andalucía y Levante, maximizando la situación de encrucijada de caminos de la villa de Bayona y las redes vertebradas por los bayoneses establecidos en esas áreas. Cuando las mercancías se adquirían en lugares distantes, los bayoneses procuraban asegurar la carga, tal y como hizo en 1734 el comerciante Forsant, con un cargamento formado por dos cajas de sedas que había comprado en Lyon, para un comerciante de La Habana, y que ordenó embarcar en Marsella rumbo al puerto de Cádiz ${ }^{42}$.

Las pequeñas dimensiones de esta villa portuaria, unido a su situación periférica dentro de Francia, explican el por qué, a pesar de la vitalidad de su élite mercantil, sus redes de aprovisionamiento se circunscribieron principalmente al espacio comercial francés, utilizando la intermediación de los puertos franceses para imbricarse en las redes de distribución del Norte europeo, del Atlántico e incluso del Levante, a través del enlace marsellés. No entra dentro de los propósitos de nuestro trabajo describir los mecanismos y circuitos de aptovisionamiento de los comerciantes bayoneses por los distintos espacios regionales europeos. Diversas monografias y los, escasísimos por otra parte, libros de facturas y de correspondencia de algunas firmas bayonesas aportan interesantes detalles al respecto.

40 Tras el abandono de Terranova por parte de Francia a raíz del Tratado de Utrech, los comerciantes bayoneses se vieron obligados a importar grandes cantidades de bacalao vía Londres, para satisfacer la fuerte demanda del mercado español. ]ANZEN, Olaf Uwe, «The Illicit Trade in English Cod into Spain, 1739-1748m: International Journal of Maritime History, junio (1996) 1-22. En este sentido cabe señalar cómo una de las firmas de origen bayonés afincada en Madrid, los Drouilhet era la que tenía el monopolio de venta de pescado en la Corte.

${ }_{41}$ ZiNk, Anne, «Une niche juridique. L'installation des Juifs à Saint-Esprit-lès-Bayonne au XVIIe siècles, Antrales H.S.S. 3 (1994) 639-669; ibid., «Les juifs du Bas-Adour au service de l'économie locales, en XXXI Settimana di Siudio de Prato all ruolo economico delle minoranze in Europa XIII-XVIII». Algunas alusiones en DERMIGNY, Lowis: op. cit., 1954, pág. 245.

42 ACCIMf-P, fonds Roux, LIX 148.

Hepuntiu, LIX/3, núm. 203 (1999) 955-987 


\section{DE BAYONA AL VALIE DEL EBRO, A TRAVES DE LA PLATAFORMA DE NAVARRA}

Los intereses bayoneses en el «metcado interior españobs se acomodaron a los circuitos tradicionales del comercio francés en la Península ${ }^{43}$, caracterizados por confluir en la ciudad de Madrid, el centro financiero y de consumo por antonomasia ${ }^{44}$. Pero también aportan una dimensión nueva, más desconocida, la del tráfico interior y terrestre en la región del Alto Ebro y la Castilla oriental. Un espacio, simplemente esbozado en los estudios sobre el problema del contrabando en el cordón aduaneto del Ebro y las medidas coercitivas adoptadas por el Estado ${ }^{45}$, especialmente durante la guerta de Sucesión y la década de los ochenta, ante las dimensiones del tráfico ilegal de la plata americana. Como es sabido, en la noción de espacio marítimo, hay que considerar tanto las regiones costeras como los binterlands irrigados por ellas ${ }^{46}$. En este sentido el puerto bayonés irradió sus intereses sobre un extenso territorio español, que comprendía regiones del interior peninsular, algo alejadas del litoral atlántico, como Navarta, La Rioja, el norte de Soria y la parte occidental de Aragón, en clara competencia con los puertos vascos de Billbao ${ }^{47}$ y San Sebastián. La creciente

43 La geografia de los cónsules franceses en España es indicativa del peso que tenían los distintos establecimientos situados en el litoral, concretamente, en las ciudades de Cádiz, Sevilla, Málaga, Cartagena, Alicante, Valencia, Barcelona, Palamós, Salou, El Ferrol, La Coruña, Gijón, Santander, Santa Cruz de Tenerife y Palma de Mallorca. La comunidad madrileña, a pesar de su influencia, nunca llegó a constituir una nación mercantil conno la gaditana. De los cincuenta comerciantes registrados en Madrid, entre 1764 y 1765, la mitad procedían del Sudoeste francés. O'zanAM, Didier, op. cit., 1991, pág. 181.

44 Ringrose, David R., Transportes y estancamiento económito de España (1750-1850), Madrid 1972; Ibid., Madrid and the Spanisb Economy (1560-1850), Berkeley/Los Angeles/London 1983; ibid., Madrid. Historia de una capital, Madrid 1994, $2^{2}$ edición; y ZYLBERBERG, Michel, «Un centre financier 'periphérique': Madrid dans la seconde moitié du XVIIIe siècle»: Revue historique 269 (1983) 264-309. Banqueros y asentitas renombrados como Jean Camps y Cia, Casamayor y Cia., Dutillot et Cia., los Drouilhet y Brethous fueron de origen bayonés o bearnés.

45 Numerosas referencias a este tráfico en los trabajos de FrRNÁNDEZ Al.13M.ADFjo, Pablo, La crisis del Antiguo Régimen en Guipuizcoa, 1766-1833: cambio económico thistoria, San Sebastián 1975, págs. 234 y ss.; MnLAMUd Rikl.ss, Catlos, Cádiz y Saint-Malo en el comercio colonial peruano (1698-1725), Jérez de la Frontera 1986; STLIN, Stanley J., "Un raudal de oro y plata que corria sin censar de España a Francia': Politica mercantil española y el comercio con Francia en la época de Carlos III): Actas de/ Congreso Internacional sobre "Carlos III y la Ilustración», tomo 2: economía y sociedad, Madrid 1989, págs. 219-280. Aunque el principal trabajo sobre esta cuestión sigue siendo el de DFRMIGNY, Louis: "Circuits de l'argent et milieux d'affaires au XVIIIe siècle»: Revue Historigue 212 (1954) 239-278. Para el tráfico de la plata por el Pirineo occidental véanse las págs. 253, 259, 263 y 266.

46 Butel, Paul, Européens et espaces maritimes (vers 1690-vers 1790), Burdeos 1997, pág. 9.

47 Hasta la construcción del ferrocarril Bilbao-Tudela, en la segunda mitad del siglo XIX, no se consolida la influencia del puerto de Bilbao sobre esta zona, a pesar de los diversos proyectos concebidos a finales del Setecientos. SAENZ DE LENZANO, Salvador, «Un antecedente de la construcción de la carretera de Logroño a Vitoria»: Berceo 3 (1947) $267-275$.

Hithaniu, L.IX/3, núm 203 (1909) 955-987 
demanda de productos coloniales y de todo tipo de manufacturas, principalmente textiles y de algunas mercancías de lujo de este espacio interregional - que Ringrose ${ }^{48}$ define como región económica - fueron, en buena parte cubiertas, según diversos mecanismos de distribución, por una red foránea que mantenía estrechas relaciones de parentesco y mercantiles con sus compatriotas de éste y del otro lado de la frontera, hasta el punto de poder hablarse de una suerte de red o solidaridad geográfica ${ }^{49}$. Algunos de estos comerciantes formaron parte de activas colonias francesas, que son bien conocidas en sus parámetros cuantitativos ${ }^{50}$. Pero el aspecto que nos interesa subrayar son las conexiones mercantiles, basadas en el parentesco y los vínculos de paisanaje, que los agentes bayoneses y bearneses radicados en la región del Alto Ebro y los territorios circundantes mantuvieron entre sí ${ }^{51}$.

La región de Navarra, en la ruta terrestre más corta que comunicaba Madrid con la frontera pirenaica, por su peculiar régimen fiscal y su no integración en el sistema aduanero español, acogió una numerosa e influyente comunidad mercantil, cuyos miembros procedian mayoritariamente del vecino Sudoeste francés ${ }^{51}$. En esta región, la frontera política situada en los Pirineos no coincida con la frontera económica localizada en el cordón del Ebro, lo que proporcionaba indudables ventajas fiscales y por ende mercantiles, tanto a los

48 Un espacio que no queda de todas formas bien encajado en los límites de las regiones económicas señaladas por Ringrose, como articuladotas de las redes de mercado y urbanas de la España del Setecientos. Ringrosli, David R., España, 1700-1900: el mito del fracasa, Madrid 1996, págs. 301 y 312. Este terntorio aparece subdivido entre lo que llama la región septentrional y la del interiot.

49 ZYluBEnBERG, Michel, Une si douce domination. les milieux d'affaires franfaises et /'Espagne, vers 1780-1808, Paris 1939. Véase al respecto la reseña de Didier Ozaman en Reyze d'bistorie moderne et contemporaine $42-2$ (1995) 320-326.

50) Para el caso concreto de Pamplona, tras cotejar los datos que aportan las series del impuesto municipal de la alcabala, con las matriculas que por mandato real se efectuaron entre 1764 y 1792 en toda la geografia española, resultan avecindados en Pamplona 29 comerciantes franceses, frente a un total de 108 inmigrantes. AHN, leg. 629, 1 y AMP. legs. 1, 2 y 3. Para fechas anteriores esas mismas series de la alcabala indican que, entre 1707 y 1721 , hubo en Pamplona 11 comerciantes franceses y entre 1722 y 1749,12 comerciantes.

51 AzCona Gubrra, Ana Mercedes, Comercio y comerciantes en la Nayarra del siglo XVIII, Pamplona 1996. «Ser representante» de una compañía bayonesa era la función por excelencia desempeñada por los miembros de la colonia francesa establecida en las dos principales ciudades navarras de Pamplona y Tudela. Ibid., «Contribution à l'étude des réseaux commerciaux dans un espace interrégional: Navarre-Aquitaine au XVIIJe siècles: Bulletin du Centre d'Histoire des Espaces Atlantigues 7 (1995) 59-84. En 1746, había en Pamplona 12 casas de comercio francesas y una en Tudela. En opinión del Consejo Real de Navarra era una colonia pequeña, pero muy influyente.

52 Ibidem, concretamente el $81,2 \%$ de los comerciantes franceses establecidos en 1764 en Pamplona, la ciudad que concentraba el mayor número de inmigrantes empleados en actividades mercantiles, eran originarios del Sudoeste francés. Diez años después, el porcentaje había disminuido ligeramente, aunque todavía se situaba en el $56,7 \%$ y, en 1784 , de nuevo alcanzaba valores próximos a la fecha inicial del recuento con el $67,3 \%$.

Hiptunta, L.IX/3, num. 203 (1999) 955-987 
comerciantes extranjeros residentes ${ }^{53}$ como a los locales. También por tradición histórica la villa de Bayona y el país de Labourd gozaban de un ventajoso régimen fiscal ${ }^{54}$, en comparación a otros territorios franceses, muy similar al de las Provincias Vascas y Navarta ${ }^{55}$, con las que mantenía estrechas relaciones transfronterizas plasmadas en constantes desplazamientos de población en dirección Norte-Sur, hacia el próspero valle del Ebro, o hacia las ciudades portuarias de Bilbao, San Sebastián y Burdeos. Sus élites mercantiles habían puesto en práctica ciertas estrategias y habilidades comerciales y financieras aprovechando ese favorable marco fiscal. Se trataba además, de un espacio relativamente alejado del radio de influencia del puerto de Bilbao, con el que había en esa época difíciles comunicaciones, pero fácilmente accesible desde el puerto de Bayona. El attactivo de la ganancia comercial había creado una rudimentaria pero muy eficaz red de transportistas, mulateros y arrieros, que cubrian las rutas pirenaicas y, cruzando Navarra de norte a sur, a través de los valles del Baztán y la Ulzama, confluían en Pamplona, y de allí se dirigían a los pasos aduaneros del Ebro 56. El pasillo comercial de Navarra había permitido a los bayoneses penetrar en el valle del Ebro, en los centros productores de lana de Soria y las sierras riojanas, y dependiendo de la coyuntura, llegar hasta Madrid ${ }^{57}$. Había un elevado

53 Ibidem. A estos extranjetos se les incentivaba a residir en Pamplona, lo que equivalía a tener casa o habitación abierta, asegurándoles un descuento del $50 \%$ en el impuesto municipal de la alcabala, que gravaba en un $4 \%$ el valor de todos los géneros extranjeros introducidos en la ciudad. Desde 1763, ante la importancia que fue tomando el fraude fiscal del «encabezamiento", se minoró ese impuesto, hasta situarlo en el 1,5\%. Cantidad, que debian pagar todos los comerciantes fuesen naturales o extranjeros. El objetivo perseguido por el municipio con esta medida fue canalizar por la via legal el abasto de géneros extranjeros de la ciudad. También los comerciantes extranjeros fueron en 1744 (primero los residentes) y en 1780 (también los transeúntes) sujetos a una nueva figura fiscal, la del impuesto de mercaderias, que gravaba el tradicionalmente exento tráfico de importación. AGN, Tablas y aduanas, leg. 5, carpeta 59 y leg. 2, carpeta 31 .

54 Privilegios fiscales que se justificaban históricamente, en virtud del procedimiento aplicado para la integración de este territorio fronterizo en la monarquía francesa. DARké, H., «La grande coutûme de Bayonne (XVe-XVIIIe siècles)m: Bulletin de la Societté des Sciences, Lettres et. Arts de Bajonne (1976) 63-84; DravasA, Etienne, Les privileges des basques du Labourd sous l'ancien régime, Bordeaux 1950. La Cámara de comercio de Bayona, principal defensora de este estatuto especial, señalaba al respecto: «les envois de toutes marchandises pour l'Espagne se fasoient courantement libremente et sans le moindre obstacles. ACCIB, B 24-41.

55 Sobre esta afluencia de comerciantes vasco-franceses a lo largo del siglo XVIII, véase para Bilbao, ZABA,$A$, Aingeru, Mundo urbano y actividad mercantil. Bilbao 1700-1810, Bilbao 1994, págs. 473 y 476 ; Fu! OO, Pilar y ORMAECIIEA, Angel $\mathrm{M}^{\mathrm{a}}$ : «Los extranjeros en las provincias vascas en los años finales del siglo XVIIL): Letras de Deusto $52-54$ (1992) 53-75.

56. Durante la década de los ochenta fueron frecuentes las cuadrillas de transportistas de la zona de Cervera y Aguilar que se desplazaban a Bayona para adquirir manufacturas que pensaban vender en las ferias de Madrid. AGS, SSH, leg. 2265.

57 Buena parte de estos bayoneses establecidos en Navarra recurrieron para sus operaciones bancarias a la intermediación de los banqueros madrileños de origen francés. Algunos de los cuales aparecen señalados por TEDDL vE LORCA, Pedro, «Comerciantes y banqueros madrileños al final del Antiguo Régimenn: Gonzalo ANES, Luis Angel ropo y Pedro TEDDE. 
número de comerciantes bayoneses y bearneses establecidos en las localidades más próximas al cordón aduanero del Ebro, la frontera económica por antonomasia de este territorio y el lugar donde se concentraba la mayor densidad del tráfico. Buena parte de las mercancias de origen extranjero - no exclusivamente francesas- eran canalizadas por estos comerciantes de origen vasco-francés, aunque algunos como los Vidarte, los Zaro, los Itúrbide y los Basset, de antigua instalación en Navarta, que llega a remontarse a finales del siglo XVII, terminasen por naturalizarse y crear su propia casa y red comercial. Contribuyendo de ese modo a la configuración de un colectivo comercial autóctono, dentro del cual sobresalieron los comerciantes laneros de la Ribera del Ebro. Sin embargo, la mayoría de los llegados, en torno a mediados del setecientos, conservaron su nacionalidad y un elevado grado de temporalidad, sin superar nunca el escalafón del comisionismo, con frecuentes idas y venidas a Bayona ${ }^{58}$. Este carácter comisionista nos evita abordar la cuestión de la integración del agente foráneo en el medio social de acogida, por la sencilla razón de no darse este fenómeno.

Todo ello no significa que los comerciantes franceses y, en concreto, el minoritario e influyente grupo de inmigrantes bayoneses y bearneses tuviesen el monopolio de los sistemas de distribución de coloniales, textiles, manufacturas de lujo y de las actividades crediticias de este espacio interregional. Tan sólo subrayamos que si esa función se dió, en buena medida fue por la habilidad con que supieron crear un tejido mercantil bien cohesionado, a este lado de la frontera, presente en los principales centros urbanos, y vinculado a las redes nacionales e internacionales del comercio y producción franceses. Tampoco cabe suponer, por lo que venimos diciendo, que en Navarra no existiese una red mercantil autóctona; en cualquier caso, la presencia de los bayoneses vino a subsanar ciertas deficiencias mercantiles del territorio, tanto por lo referente al aprovisionamiento de mercancías como a la comercialización en mercados extranjeros de materias primas, principalmente de la demandada lana. El relativo control y las interferencias que fue capaz de introducir el comerciante bayonés en el mercado lanar de la cabaña soriana y navarro-riojana mediante adelantos de dinero, reventas y acaparamientos apunta la existencia de un soporte financiero potente. Cabe incluso formular la hipótesis de que el repliegue comercial "francés» ${ }^{5 "}$, documentado en Guipúzcoa y Vizcaya a finales del siglo XVII,

(eds.), Historia económica y pensamiento social, Madrid 1983, págs. 301-315; ibid., «Banca y banqueros privados en el reinado de Carlos III": Attas del Coloquio Internacional 'Carlos III y su siglo h, Madrid 1988, tomo I, págs. 235-261. Pero sobre todo debe citarse el artículo de ZÝlBERBERG, Michel, op. cit., 1983.

58 El grado de permanencia de los inmigrantes de Pamplona fue de 7,9 años, frente a los 2,6 años de los de Tudela y a los 1,4 años de Corella. Este grado de permanencia en la capital de Navarra confirma la importancia mercantil de la ciudad dentro del entramado comercial del Reino.

5) Gonź́LEz, Alfonso F, La realidad económica guipuz̧oana en los años de superación de la crisis económica del sigho XVII (1680-1730), San Sebastián 1994, pág. 186; LABOron, Juan José, «E1 arranque de un largo protagonismo: la recuperación comercial de $V_{j z c a y a}$ a comienzos del siglo

Hicpunta, 1.1X/3, núm. 203 (1999) 955-987 
fuese compensado con la expansión francesa por la región del Alto Ebro que ofrecía la doble ventaja, de servir de enlace con el principal centro de consumo del país, Madrid, y de proporcionar buenos accesos a la cabaña lanar soriana y riojana. El mantenimiento y estabilidad de esta red estuvo garantizado por la continua remesa de jóvenes bayoneses acogidos en calidad de factores, empleados y algunos elevados incluso, con el transcurso del tiempo, a la categora de socios, en el seno de las Casas comerciales que sus compatriotas habian establecido en España. Esos jóvenes poseían un alto grado de disponibilidad y de movilidad espacial. No es raro observar que en su deseo de probar fortuna, fuesen pasando por distintos lugares de la geografía española, algunos bien alejados entre sí ${ }^{60}$. En última instancia, sin embargo, la solidez del entramado comercial dependía de la estabilidad de las firmas radicadas en Bayona y de su capacidad crediticia. De ahí el interés que dejamos para más adelante, de estudiar los canales de financiación de estas casas de comercio bayonesas, a través de los intermediarios franceses que sostenían dicho tráfico, mediante el giro y descuento de letras.

Para comprender los mecanismos de funcionamiento de esta red, debemos fijarnos en la organización del tejido urbano y de mercado de este espacio económico, ya que el número de agentes radicados en cada localidad, es decir, la densidad de la red en ciertos tramos y puntos, estaba en relación a sus funciones distributivas y de consumo, actuando éstas de nudos de difusión mercantil sobre las áreas circundantes. A lo largo de esta centuria no hace sino consolidarse un tejido urbano de origen medieval donde caben distinguirse tres áreas: la Ribera del Ebro, que presenta una fuerte densidad urbana, en la que destacan las ciudades de Corella, Cintruénigo, Tudela y Fitero, próximas a la frontera castellana; Tierra Estella ${ }^{61}$, cuya capital actúa de gran centro lanero, buena parte de las lanas legaban vía Logroño, y la ciudad de Pamplona ${ }^{62}$. En esta última, los comerciantes suponían en 1787 el $30,05 \%$ de la población activa.

XVIIIn: Revista de estudios vascos. Saioak 2 (1978) 136-182; ZıВALA, Aingeru, op. cit., 1994, págs. 473 y 476 . Este último señala que no está tan claro el hecho de la retirada, aunque se constate cómo efectivamente, desde 1740 , la presencia extranjera habia minorado, gracias a que buena parte de los inmigrantes se labian integrado en la sociedad bilbaina.

(w) Un ejemplo de entre los muchos que podviamos citar ilustrativo de esta movilidad, fue el del comerciante beamés Diego Carrère. En la década de los setenta, este joven mercader, natural de Olorón, llegó a Pamplona para trabajar de aprendiz en la casa de comercio que tenía su pariente Francisca Gajes. Al poco tiempo, pasó a Alicante donde estuvo por espacio de doce años empleado en la casa de comercio de otro familiar. Con el dinero que logró reunir en esa larga estancia regresó a Pamplona y se estableció como lonjista, casándose con una pariente que había traído consigo de Alicante. En 1794, al estallar la guerra contra la Convención, solicitó a las Cortes de Navarra la carta de naturaleza, y aunque le fue concedida su situación no debió mejorar, ya que en 1805 lo encontramos en Madrid. AGN, Naturalizaciones, leg. 4, carpeta 67.

61 Floristîn Imizcoz, Alfredo: La Merindad de Estella en la Edad Moderna: los bombres y la tierra, Pamplona 1982.

62 GEMiliro UsIŔrroz, María, «Pamplona en el siglo XVIII: aspectos demográficos, económicos y socialesm: Actas del Noveno Congreso de Estudios Vascos. Antecedentes próximos de la Sociedad 
La actividad comercial de estos comerciantes no se limitaba a la mera función distribuidora de manufacturas extranjeras ${ }^{63}$, sino que tenía su lógico contrapeso en la importación de lana y de ottos productos del agro (sosa, seda, esparto, aceite, barrilla, regaliz ${ }^{64}$ ) destinados a la comercialización en el mercado francés, según una espacialización definida por áreas productoras. El relativo control - preferentemente sobre la cabaña soriana y navarro-aragonesaque el comerciante bayonés consiguió establecer sobre este sector productivo "clave" ${ }^{65}$ de la economía española, y las interferencias que fue capaz de introducir en el mercado lanar -mediante adelantos de dinero, teventas y acaparamientos- apuntan la existencia de un soporte financiero potente. De ahí, el interés que dejamos para más adelante de estudiar los canales de financiación de estas casas de comercio bayonesas, a través de los intermediarios franceses radicados en Cádiz, Madrid, Marsella, Lyon y París, que sostenían dicho tráfico mediante el giro y descuento de letras.

\section{LA "CASA" COMERCIAI BAYONESA ${ }^{66}$}

Aunque nuestro conocimiento sobre las formas de organización, los mecanismos de funcionamiento y las estrategias de las casas comerciales ${ }^{67}$ francesas

Sociedad Vasca actual. Siglos XVIII y XIX, San Sebastián 1983, págs. 431 433. A principios del siglo XVIIJ Pamplona tenía 10.000 habitantes y en 1787 había alcanzado la cifra de 15.000. A ello había contribuido sin duda una importante masa de inmigrantes. Prueba de ello es que en el $68 \%$ de las nupcias contraídas en el siglo XVIII uno de los cónyuges fue extranjero.

6.3 Los stocks de las lonjas de estos comerciantes descubren una gran diversidad de tejidos de lana, seda, lino y algodón, lo que también se confirma por los aranceles de aduanas.

64 En 1786 funcionaba en Corella (Ribera de Navarra) una fábrica de extracto de regaliz regentada por el francés, Juan Bautista Duclos, donde estaban empleados un elevado número de inmigrantes franceses. La producción se enviaba a través del agente francés de Pamplona, Agustín Laserre, al puerto de Bilbao, a la conocida firma bayonesa «Beltrán Douat, Lavat y Plantés. APNT, escribano Manuel Renault.

65 Las investigaciones sobre la economía lanar española han profundizado, sin duda debido al tipo de documentación disponible, más en el estudio de la produccion que en aspectos tales como la comercialización, limitándose en estos casos a exhaustivos trabajos cuantitativos que señalan el volumen y la geografia de las exportaciones. Actualmente disponemos de un nitido cuadro de los sistemas y mecanismos de la producción lanar. Pero como varios especialistas han apuntado no es suficiente con conocer la geografia de los mercados receptores, los circuitos de distribución y los puertos de embarque, también es preciso analizar qué mecanismos de crédito articularon en el pasado la venta y consumo de lana española en los mercados regionales europeos. La documentación notarial y la correspondencia de algunas firmas bayonesas arrojan cierta luz sobre los complejos mecanismos de comercialización de la lana espanoola en el espacio regional francés (concretamente del Sudeste). Véase al respecto AzCONA Guiskr, A.M., «Une entreprise navarraise dans le réseau commercial de la France méridionale: les Vidarte (1754-1823)m: Annales du Midi 216 (1996) 479-505.

16. Para completar la faceta del comercio autóctono de la región navarra véase AzCoNA Guerrs, A.M., "Pautas de análisis de la estructura familiar del negocio comercial navarro en el siglo XVIIIn: Francisco CiInCÓN y Llorenç Ferrer (eds.), Actas del Congreso Historia de

ili.puniu, 1.IX/3, núm. 203 (1999) 955-987 
y por ende, bayonesas o bearnesas, tadicadas en España haya avanzado considerablemente en los últimos años, todavía carecemos de un sistemático estudio que ponga de relieve las relaciones de parentesco, las distintas formas de asociación y de correspondencia mercantil, las reglas seguidas en los negocios y las vinculaciones de estos comerciantes, dentro y fuera de España, al objeto de poder determinar hasta qué punto sus modos de operar respondieron exclusivamente a intereses de casas de comercio y banca asentadas en suelo francés, o si por el contrario hubo un cierto grado de intermediación y/o autonomía. El estudio de García-Baquero ${ }^{68}$ sobre el comercio de Cádiz subraya la variedad de estructuras internas que presentaban las casas mercantiles francesas alli tadicadas, desde las individuales hasta las colectivas, con una clara tendencia estas últimas a incrementar el número de socios y empleados, y en los jugosos relatos sobre las compañías de Antonio Granjean y de Los Fornier ${ }^{69}$ de Cádiz, apreciamos con todo lujo de detalles, las conexiones familiares de estos comisionados franceses, integrados en las redes de aprovisionamiento y distribución de importantes casas de comercio francesas, fuertemente capitalizadas. Otro tanto puede decirse del estudio de Zylberberg, sobre la compañía de los Huguet $i$ Dupré radicada en Barcelona y de las firmas bearnesas examinadas por Ricardo Franch en Valencia, donde la nota predominante son los lazos de parentesco que ligaban a los diversos miembros de las sociedades y compañías, lo que con frecuencia hacía innecesario el registro notarial ${ }^{70}$, dado el grado de confianza reinante entre sus miembros. Es decir, los casos de inmigrantes aventureros que actuaban por su cuenta fue práctica poco frecuente y raramente condujo al éxito comercial; en cambio, la "llamada» de jóvenes miembros de una extensa familia para formarse en los establecimientos comerciales, que sus parientes o allegados tenían en España, era la trayectoria vital seguida por

la Familia. Una nueva perspectiva sobre la Sociedad Europea, Familia, Casa y Trabajo, Murcia 1997, págs. 345-371.

67 Este término se ajusta mejor al funcionamiento de una casa de comercio de antiguo régimen, JEANNIN, Pierre, «Les practiques commerciales des marchandes étrangeres dans les ports français (XVIe-XVIIIe siècles; L.M. Culles y P. Buttil (dirs.), Actes du Colloque franco-irlandes d'bistoire, Négoce et industrie en France et en Irlande aux XVIIIe et XIX siècles, Burdeos 1978 , pág. 9 y ss.

iy Garcin-Baquero, Antonio y Coljado Villatta, Pedro, «Les français à Cadix au XVIIIe siècle: la colonie marchanden: VVAA, Les francais en Espagne à l'époque moderne (XVIeXVIIIe siècles), Paris 1990, págs. 173-197. Apuntan la existencia de casas de comercio en las que existía una jerarquáa ocupacional interna, según la función desempeñada por los individuos que la integraban, fuesen asociados, empleados de oficina, domésticos o agregados.

69 CHAMBORIDON, Robert, «Une société de commerce languedocienna à Cadix: Simon et Aranil Fornier et Cia.s (1768-1786)): Antonio GarciA-BAQuero (ed.), La burguesia de negocios en la Andalucía de la Ilustración, Jerez de la Frontera 1991, págs. 35-55; DORNIC, François, «Le commerce des français à Cadix d'après les papiers d'Antoine Granjean (1752-1774)w: Annales E.S.C. 9 (1954) 311-327.

70 Zyt.BERBLisci, Michel, ('Huguet y Dupré, una societat comercial de Barcelona»: Recerques 12 (1982) 91-116 y Franci BENAVI⿰NT, Ricardo, op. cit.

Hepanta, l.JX/3, núm. 203 (1999) 955-987 
la mayoría de ellos. Con el tiempo, algunos pasaban a la escala de socios e incluso, unos pocos, llegaron a establecerse por su cuenta, con el capital que habían conseguido reunir, vertebrando entonces su propia red de distribución a minoristas.

Debemos aclarar a la hora de examinar la organización interna de estas Casas bayonesas, que no difiere en gran medida de otras compañías francesas afincadas en España, ni de las «empresas» comerciales propias de la etapa preindustrial. Igual que ellas pivotaban sobre una estructura familiar con mayor o menor grado de parentesco ${ }^{71}$, y mostraban una solidaridad comercial y una tendencia corporativa, a través de los diputados de comercio de la nación francesa y consulados, donde los hubiere, a la hora de defender sus intereses mutuos $^{72}$. Es decir, el adjetivo bayonés apunta simplemente a ventajas mercantiles derivadas de su localización portuaria y fronteriza, y a la configuración de una red geográfica de fuerte implantación en la región del Alto Ebro y su átea circundante, pieza clave de una cadena comercial de más largo recorrido.

La empresa-tipo responde al esquema de una Casa-madre con sede en la villa-puerto de Bayona (epicentro de la red) y una filial o sucursal en suelo navarro, preferentemente en la ciudad de Pamplona, al frente de la cual se situaba un pariente o parsano, por una indudable cuestión de economía de costes y de garantía de fidelidad a la "empresa». Este sistema conllevaba una serie de ventajas fiscales: la Casa-madre o, lo que es lo mismo, el comerciante bayonés pagaba «en virtud del derecho de la costumbre» reducidas tasas aduaneras por las mercancías que importaba del exterior y posteriormente pasaba a España, a través de la frontera pirenaica. A su vez, al encabezar esas mercancías sobre sus

71 Así por ejemplo, en 1751, la compañía bayonesa de los Barrau, a instancia de sus parientes establecidos en Cádiz, la firma Lapetre, Taules at Cie compró una partida de creas y otra de telas ligeras para enviatlas a los mercados andaluz y levantino. Pensaba obtener con la operación un beneficio de entre un 10 a $12 \%$ del capital invertido. La experiencia sin embargo se abandonó al poco tiempo, ante la escasa perspectiva de rentabilidad, en una coyuntura marcada por la disminución del poder adquisitivo de los consumidores españoles. Un año más tarde, en 1752, Barrau decidió participar con otro sobrino, también establecido en Cádiz, en una expedición formada por varios navios de registro de 600 toneladas cada uno, que se dirigían al puerto de Veracruz. Un reciente estudio pone de manifiesto estas redes de parentesco, FERNÁNDEZ l'ERi:z, Paloma, El rostro familiar de la metrópoli. Redes de parentesco y lazos mercantiles en Cádiz, $1700-$ 1812, Madrid, 1997.

72 La Cámata de comercio de Bayona fue el interlocutor, que aglutinó y defendió los intereses de la clase mercantil bayonesa. LLON, Pierre, Étude sur la chambre de commerce de Bayonne, Bordeaux 1869; última edición, Marseille 1993. En suelo navarro los comerciantes franceses tuvieron diputados — generalmente los más adinerados-que canalizaron a través del embajador francés en España la defensa de sus intereses. Así por ejemplo, cuando las Cortes de Navarra decidieron en 1744 incrementar los impuestos sobre el tráfico mercantil —el liamado impuesto de mercaderías - con el que pensaban recaudar el servicio ofrecido por el Reiso a la Corona, estos diputados hicieron llegar al embajador francés su malestar e inquietud, por una medida que entendían vulneraba los acuerdos comerciales firmados entre los dos países. AGN, ASCR, Subsección $3^{3}$, libros de gobierno y administración, consultas al virrey, $n^{\circ} 39$, libro 34 , fols. 30 $89 \mathrm{v}$.

Hiphunia, LJX/3, núm 2013 (19Y9) 955-987 
comisionados y factores bayoneses avecindados en Navarra también veía minoradas las tasas, que se cobraban a los extranjeros en las tablas o aduanas de Navarra ${ }^{73}$. Desde la filial de Pamplona se controlaba un extenso territorio, mediante una ted jerarquizada de agentes, vinculados por lazos de parentesco $\circ$ simplemente de paisanaje, a la compañía bayonesa. Estos agentes estaban ubicados estratégicamente en los principales centros distribuidores de la trama urbana, como eran las ciudades capital de merindad - Estella, Tudela, Tafalla, Olite- y las localidades más importantes de la Ribera del Ebro, próximas a la frontera castellana. También disponía en el espacio circundante de una compleja red de proveedores, especialmente de lana castellana. La distribución mercantil combinaba la venta al por mayor, con almacenes situados en Pamplona y una red de minoristas a los que regularmente se abastecía, localizados en los restantes centros urbanos del territorio ${ }^{74}$. El sistema se completaba con la petiódica asistencia a las ferias de ámbito regional e interregional, frecuentadas habitualmente por éstos y otros comerciantes de las áreas vecinas. La importancia que todavía tenían las ferias de origen medieval como mecanismo de abastecimiento y de pagos en Navarra pone de manifiesto la debilidad de la demanda, aunque se constate la tendencia a su concentración en Pamplona ${ }^{75}$, en detrimento de otras ferias de ámbito comarcal. El consumo regular de productos extranjeros no se cubría sólo por el mecanismo estable de la agencia mercantil; las ferias, con lo que entrañaban de movimiento itinerante de mercancías y comerciantes, constituían una vía fundamental para asegurar el abastecimiento de una sociedad eminentemente rural. Los bayoneses avecindados y con casa abierta en Pamplona, o los que simplemente se desplazaban regularmente desde Bayona para asistir a las ferias, aunque fuesen los proveedores por excelencia de mercancías extranjeras, no controlaban el proceso subsiguiente de distribución mercantil. Los minoristas locales y foráneos, así como el colectivo de comerciantes ambulantes de los territorios circundantes, pero, sobre todo, los lonjistas de Pamplona eran los clientes por antonomasia de estos extranjeros, y los que se encargaban de cumplir la función distribuidora en el territorio. De modo que entre unos y otros, existía una complementariedad jerarquizada de funciones comerciales.

Para poder ejemplificar la estructura y organización de esta red comercial bayonesa hemos escogido dos firmas, relevantes por la cuantía fiscal de su con-

73 Esta forma de fraude fiscal fue duramente perseguido por los arrendadores de las tablas de Navarra. A lo largo de la centuria, las Cortes, progresivamente lograzán, mediante la creación de un nuevo impuesto, llamado de mercaderias una mayor sujeción fiscal sobre los comerciantes extranjeros xesidentes.

74 Una serie de quiebras, cuya documentación se conserva en el APNP, de mercaderes de Almazán, Tudela, Sastrica (Aragón), Estella, Corella, Pamplona, Sangüesa, Tarazona, Tafalla, Caparroso, Zaragoza, Fitero, Egüaras y Agreda descubren la importancia, que los acreedores bayoneses tuvieron en los sistemas de aprovisionamiento de este espacio interregional.

75 En 1744 , el $50 \%$ de las mercancías importadas por los comerciantes extranjeros residentes en la ciudad de Pamplona, el principal centro de abastecimiento de Navarra, se introdujeron en los días previos a celebrarse Ja fena franca de San Fermín.

11i.pantia, 1.1X/3, núm 203 (1999) 955-987 
tribución municipal ${ }^{76}$ en la ciudad de Pamplona, y de las que hemos podido consultar, algo poco frecuente, una parte de su correspondencia mercantil y las escasas huellas que han dejado en protocolos notariales, en algunos censos ${ }^{77} \mathrm{y}$ fuentes fiscales. Estas limitaciones documentales explican, la insuficiencia que puede resultar en algunas ocasiones de la exposición. Su campo de actuación no se ciñó sólo a Navarra, aunque este territorio fuese la base principal de operaciones, sino que también tuvieron proyección sobre otras áreas y regiones españolas.

\section{LA COMPAÑIA DE LOS BARRAU: UN EJEMPLO DE FIRMA IMPORTADORA}

Nos consta la existencia de la firma Barrau y de su filial navarra desde el año 1727. En esa fecha, Juan de Larroder ${ }^{78}$, bearnés avecindado en Pamplona, ostentaba junto a su esposa la representación de la firma de su primo, el bayonés Francisco Barrau, sobre la que estaba interesado en una cuarta parte. Todo su capital e incluso la dote de su esposa lo había invertido en la compañia. Seguía en cierto modo la tradición familiar de su esposa, cuyo padre había sido también representante en Navarra de un pariente bayonés. La estrecha colaboración entre el factor navarro y la Casa Barrau de Bayona duró cincuenta y cinco años, hasta la década de los setenta. En 1775, cuando la firma Barrau fue absorbida por la compañía bayonesa «Bezian y Casadavant, la viuda de Latroder, que desde la muerte de su esposo en 1771 había asumido la representación del negocio, empezó a poner de manifiesto sus discrepancias con la casa-madre. Aunque hasta el año de $1782^{77}$ no se decidió a comunicar a su principal el deseo de disolver la Sociedad, argumentando que deseaba - trabajar particularmente con más tranquilidad ${ }^{80}$. A partir de esa fecha comienza la andadura independiente de la filial navarra bajo la razón de «Viuda de Larroder, hijo y Cía.). Pero el período que a nosotros nos interesa es justamente el inmediata-

76 En 1764 , pagaron $200 \mathrm{rs}$. anuales de alcabala municipal y a partir de $1765,140 \mathrm{rs}$ y 120 rs. respectivamente, lo que les situaba en la cúspide de la jerarquía mercantil.

77 AMP, Correspondencia, leg. 18 y lo mismo en AHN, Estado, leg. 629, 1.

78 Juan de Larroder de origen bearnés se estableció en Pamplona después de la Guerra de Sucesión como representante (por lo que percibía un dos por ciento de las ventas) de la firma de su primo, Francisco Dabbadía Barrau de Bayona. En 1732 estaba avecindado en Pamplona, y en 1756 contrajo matrimonio con Juana Maria Pauca, hija también de comerciantes bearneses. Un año después de la boda solicitó la carta de naturaleza a las Cortes de Navarra.

79 APNP, escribano Manuel Nicolás de Arrastia, uescritura de separación de sociedad de comercio y obligación de pago de 455.189 rs.» (14/5/1782). Las partes implicadas fueron Juana María Pauca, en calidad de heredera de Juan de Larroder y Gabriel Javier Bernardo Dabbadia Barrau, heredero del bayonés Francisco Barrau. Actuó de testigo el comerciante navarro Martín Barbería.

80 En 1780 Casadevant se retiró por problemas de salud y cinco años después se produjo la fusión con el comerciante Pierre Bezian. A partir de ese momento la razón social de la compañía bayonesa sería «Bezian ainé \& Cie».

Hitpania, J.1X/3, núm 203 (1999) 955-987 
mente anterior, es decir el que va de 1727 a 1785, cuando la sucursal de Pamplona estuvo vinculada a la firma de Bayona, cobrando por su función comisionista el $2 \%$ de todas las transacciones mercantiles.

Aunque la exposición se ciña a esta compañía, lo cierto es que las actividades mercantiles que se van a relacionar pueden ser perfectamente extrapolables al modo de operar de los comerciantes franceses en otras regiones españolas.

\section{La funcionalidad de la red: la comercialización de filbras y tintes españoles en el mercado francés}

\section{a) Lana}

Desde mediados del seiscientos, los comerciantes bayoneses habían empezado a ejercer un importante papel dentro del sector exportador de la lana navarra, riojana y soriana, aventajando claramente a los comerciantes donostiartas ${ }^{81}$. Un siglo después, varias compañías bayonesas con sucursales en Pamplona - los Barrau, Daguerre, Lalanne, Lamota - se encontraban entre las principales dedicadas a la exportación lanar ${ }^{82}$, en clara competencia con los comerciantes locales. Estas firmas disponían de una red de proveedores en los principales centros productores y/o recolectores de Navarra - Sangüesa, Corella, Fitero, Falces, Aibar, Andosilla - y de intermediarios, encargados de entablar correspondencia con los ganaderos de la Castilla oriental. Los responsables franceses de la sucursal cobraban una pequeña comisión por cada arroba de lana exportada y en algunos casos hasta un porcentaje sobre las ventas.

En la aduana general de Pamplona, nudo central de la trama urbana y fiscal del Reino, los agentes bayoneses registraban las sacas de lanas finas y lavadas, que en carretas y a lomos de mula llegaban procedentes de Cameros, la Sierra de la Demanda y la Tierra de Soria para ser enviadas a la villa de Bayona. A su vez, las lanas burdas de Navarra y Aragón se encaminaban principalmente al centro textil de Olorón en Bearne. Los bayoneses y sus socios navarros también solian adquirir algunas partidas de lana, de las de mejor calidad, a ganaderos residentes en Madrid, Cáceres, Segovia y Sevilla, que canalizaban para su exportación a los puertos españoles más próximos. Todas estas compras se hacian por adelantado y se abonaban en efectivo, gracias a la intermediación financiera de las casas de banca de Marsella, que giraban letras sobre la plaza de Madrid y Bayona, lo que les permitía influir en el precio a la baja.

Para la contratación, lavado, embalaje y preparación de los fardos tenían estas casas personas de confianza destacadas en las distintas áreas. El perfil-tipo del corresponsal permite una clasificación según la función desempeñada den-

"1. Fi:rnándi:z Albaladijo, Pablo, La crisis del Antiguo Régimen en Guipuzizoa, 1766-1833: cambio económico e bistoria, San Sebastrán, 1975, pág. 84

82 ACCIM, fonds Roux (Carta de Barrau, 4-7-1767). «... es verdad que no hago otro comercio que el de mi casa de Pamplona que es, puede decirse, únicamente en lana». 
tro de la red exportadora fuese cargador, consignatario, depositario de lanas o fabricante.

Agentes y corresponsales de la compañia Barrau

\begin{tabular}{|c|c|c|c|}
\hline Nombre & Lugar & Tỉpologîa & Función \\
\hline 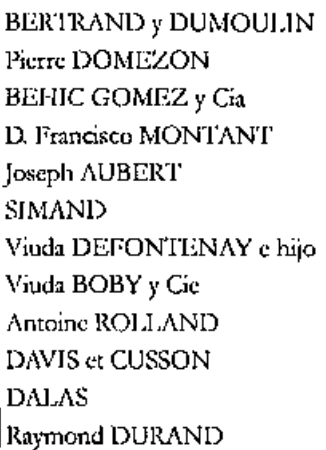 & $\begin{array}{c}\text { Cartagcina } \\
\text { Cartagena } \\
\text { Scvilla } \\
\text { Cádiz } \\
\text { Marsclla } \\
\text { Agde } \\
\text { Rouen } \\
\text { Rouen } \\
\text { Carcasona } \\
\text { Carcasona } \\
\text { Carcasona } \\
\text { Burdeos }\end{array}$ & $\begin{array}{c}\text { cargador de lanas } \\
\text { cargador de lanas } \\
\text { cargator de lanas } \\
\text { cargador de lanas } \\
\text { consignatario de lanas } \\
\text { consignatario de lanas } \\
\text { consignatario de lanas } \\
\text { consignatario de lanas } \\
\text { depositario de lanas } \\
\text { fabricante } \\
\text { comisionario de lanas } \\
\text { comerciante local }\end{array}$ & $\begin{array}{l}\text { receptor de lanas } \\
\text { cónsul de lispanana } \\
\text { venta a fabricantes } \\
\text { venta a fabricantcs } \\
\text { distribución a los fabricantes } \\
\text { trato prefercnte } \\
\text { garantc de los compradores } \\
\text { corresponsal }\end{array}$ \\
\hline
\end{tabular}

liuente: claboración propia a partir de la correspondencia cesaminada de csta firma.

Si la adquisición de lanas en los centros productores españoles parece no entrañar por la documentación examinada excesivas dificultades, en cambio comprobamos la problemática inherente a la comercialización en el mercado francés, concretamente en la zona de Catcasona y Languedoc, donde debían someterse a lo que con frecuencia aparece en la correspondencia como - la ley del fabricante- - La compañía de los Barrau mantuvo estrecha correspondencia con comerciantes de la zona del Midi, principalmente de la ciudad de Toulouse, al objeto de canalizar vía terrestre las remesas de lanas a las fábricas del área de Carcasona ${ }^{83}$. En Toulouse había una infraestructura de almacenes y residía un colectivo de factores que permitía la rápida expedición de las lanas a los fabricantes, aprovechando las oportunidades ofertadas en cada momento por el mercado ${ }^{84}$. Los envíos se hacían bien por tierra, desde Bayona hasta Carcasona, o bien vía marítima, desde los puertos del Levante español hasta Marsella, principal centro redistribuidor de lanas en esa zona. Cuando había problemas de salida en el Sudeste, las lanas

83 Marquié, Claude, L'industrie textile carcassonnaise au XVTIIe siècte. Étude d'un groupe social. Les marthands fabricants, Carcasona 1993.

84 En 1758, Barrau se lamentaba en carta remitida a los Roux de Marsella de las irregularidades cometidas en las ventas de lanas por su hombre de confianza, Dalas de Toulouse. Barrau determinó enviar una persona para examinar los libros de Dalas, incluso pensó en llevarle a los tribunales.

Hiaptaniti, 1.JX/3, núm. 203 (1999) 955-987 
eran enviadas ${ }^{85}$ al puerto normando de Rouen ${ }^{86}$, para su posterior venta a las manufacturas del Norte parisino.

De facto, existía una perfecta distribución geográfica según las distintas calidades de lana. En los puertos del Norte (Bilbao, Santander y Bayona) la compañía ordenaba a sus agentes el embarque de las lanas más catas y finas, que habían sido cuidadosamente lavadas y tratadas para disminuir su peso y economizar las subsiguientes tasas aduaneras. El principal lugar de destino de esas lanas era el puerto de Rouen. En cambio las lanas de Soria o R se embarcaban en los puertos de Valencia, Alicante, Cádiz y Cartagena rumbo a Marsella. La razón de ese desdoblamiento venía determinado por las diferencias en la cotización de las lanas, lo que a su vez dependía de las variaciones impuestas por la producción. Así, mientras la clientela de los paños fabricados en el Sudeste francés se localizaba en el Levante ${ }^{87}$ (Túnez era el principal mercado receptor de lanas españolas de calidad inferior), los centros productores del Noroeste estaban especializados en la fabricación de manufacturas de lujo destinadas a un exigente consumidor europeo o americano, de elevada capacidad adquisitiva. El intermediario bayonés era el que seleccionaba el mercado más adecuado para cada tipo de lana, en su afán de obtener la máxima rentabilidad del producto ${ }^{88}$.

La complejidad inherente a la comercialización obligó a las furmas bayonesas a buscar la colaboración de importantes casas de banca marsellesas como los Roux ${ }^{89}$, a los que llegaron a ofrecer su participación en un tercio de las

85. ACCIM, fonds Roux, carta (15-2-1772). El transporte de lanas podia hacerse aprovechando la salida de algún barco que de Marsella fuese a Rouen o Le Havre e hiciese escala en Bayona. Los costes de transporte corrían siempre a cargo de Barrau.

86. ACCIM, carta de junio de 1739. Los comerciantes de Rouen obtenian por la venta a largo plazo de las lanas a los fabricantes de la región, una comisión del $5 \%$ en concepto de garantía, pues la distribución se hacía a pequeños fabricantes que podían declararse insolventes con cierta facilidad.

87 Morinesu, M., «Naissance d'une domination. Marcliands européens, marchands et marchés du Levant aux XVIIIe et XIXe sièclesn: VVAA., Actes des Journées d'Études Bendor, 25-26 auril, Commerce de gros, commerce de détail dans les pays méditérranéens (XV/e -XIXe siècles), Nice 1976, págs. 145-184.

88 ACCIM, fonds Roux, carta (13-4-1773). Barrau pide información puntual a los Roux sobre el curso de las lanas españolas en Marsella. En 1773, las lanas de mejor calidad (R de Soria y segovianas) se vendian a 84 y 85 ecus/quintal peso de Marsella. Barrau consideraba que este precio hacia poco rentable las ventas en esa zona, aunque para ahorrar costes se enviasen las lanas en mal estado, es decir, con un lavado irregular. Son numerosas las quejas de François Barrau a los Roux porque no habían exigido a los fabricantes el precio esperado, tal y como se recoge en este fragmento que hemos traducido: «aunque fuese de la más bella lana de España, los fabricantes de Languedoc no pagarian un sueldo más que la lana de Soria (...) en Rouen estas lanas habrian obtenido una mayor rentabilidad. En Languedoc no se cotizan tanto como ellas valen, debido a los bajos costos con que deben venderse los paños para poder ser comercializados en el Levante,s ACCIM, Carta (3/1739).

8) En opinión de Francisco Barrau, una de las firmas más ricas y sólidas «de lo cual yo le doy mi entera confianzas.

Hitiputia, LIX/3, núm. 203 (1999) 955-987 
compraventas, o de significativos comerciantes de Rouen y Orleans, expertos conocedores del funcionamiento industrial de sus respectivas áreas. En esa misma línea de facilitar las ventas, se concedían créditos a los fabricantes poco capitalizados, que iban de los seis meses y un año a los quince meses, siempre que un comerciante ${ }^{30}$ saliese garante del fabricante. Cuando el pago se hacia al contado se ofertaban descuentos de hasta un $6 \%$ sobre el precio estipulado.

Además de los costes de transporte -incluidos los seguros marítimos e impuestos aduaneros - los comerciantes bayoneses contabilizaban las comisiones, en torno a un $2 \%$, exigidas por los distintos agentes de la red comercial. Todos estos costes debían deducirse de los márgenes finales de beneficio. Durante la década de los setenta, el precio de la lana española osciló entre los $70 \mathrm{y}$ 75 ecus por quintal, para la lana comercializada en Languedoc, los 100 ecus 100 libras para la lana $\mathrm{R}$ o segoviana, cuyo destino preferente era el Noroeste, y los 90 ecus/ quintal para las lanas de Albarracín, Molina o en surtido. En el mercado marsellés las lanas españolas concurrían con las lanas comunes o bajas suertes berberiscas procedentes de las llamadas escalas del Levante, lo que más de una vez obligó a rebajar los precios de venta. A su vez, el puerto de Marsella era el intermediario por excelencia de la lana española enviada al mercado italiano, concretamente, al puerto de Livorno, y a los mercados norteafricanos de Túnez y Argelia.

\section{b) Seda murciana en el mercado lyonés}

Los canales de comercialización de la seda murciana, una de las tradicionales actividades exportadoras del Levante español, desde el puerto de embarque de Cartagena hasta Marsella — su centro redistribuidor en el mercado del Sudeste francés- estuvo en buena parte controlado también por algunas casas de comercio bayonesas, que mantuvieron agentes y factores destacados en la región ", a mediados del siglo XVIII, coincidiendo con el ciclo ascendente de producción de la sericultura murciana ${ }^{92}$. El factor de la firma Barrau, llamado Pierre Domezon, compró y envió fardos de seda desde Cartagena a los consignatarios localizados en Marsella ${ }^{93}$. Domezon solía quejarse con relativa frecuencia, en la correspondencia que mantenía con su principal bayonés, de las

20 Por ello percibía entre un 1 o $2 \%$ de comisión.

91 ZylBerberg, Michel, op. cit., 1993, pág. 112. En 1740 habia en Cartagena nueve casas de comercio francesas dedicadas al comercio al por mayor, en siete de las cuales sus titulares eran bearneses. Estas casas tenían a su vez pequeños establecimientos o tiendas regentadas por empleados.

ig2 Péreź PICazo, María Teresa y Limuniler, Guy, «La sericultura murciana. Producción, difusión y coyuntura, siglos XVI-XX»: Revista de Historia económica 5 (1987) 553-575. Entre 1710 y 1896 se constata un ciclo de prosperidad, que ofrece un perfil en forma de meseta, con una cota máxima en el decenio que va de 1740 a 1750 , momento en el que está operando en la región, la firma Barrau a través de su agente Domezon.

9.3 Ibidem, pág. 565.

Hispania, J.JX/3, núm. 203 (1999) 955-987 
dificultades que entrañaba la adquisición de sedas, ya que las mejores eran reservadas para los fabricantes españoles.

Tampoco la distribución de esta mercancía en el mercado francés, concretamente entre las fábricas del lyonesado, resultó tarea fácil, pues debían competir con las producidas por los países del Levante, que también llegaban en grandes cantidades al puerto marsellés ${ }^{94}$.

Periódicamente, los factores franceses enviaban a sus principales detallados informes de los fardos de seda comprados, señalando el volumen y peso neto de la carga, los costes de transporte y las comisiones percibidas por los capitanes de los barcos encargados de su conducción hasta Marsella. Como el transporte por mar entrañaba elevados riesgos --las sedas podían mojarse, lo que deterioraba el producto y minoraba el precio final de venta-, normalmente optaban por asegurar la carga para el trayecto comprendido entre Cartagena y Marsella. Generalmente estas firmas insistían a sus corresponsales marselleses que procurasen la venta rápida de las sedas, permitiendo descuentos de hasta un 5 y $6 \%$, si el pago se hacía al contado y de un $41 / 2 \%$ si se demoraba en un plazo de quince días. Una vez cerrada la operación, los socios marselleses, según el curso de cambio más ventajoso de las principales plazas bancarias, escogían una u otra (Lyon, Paris, Madrid o Amsterdam), para girar letras a favor de sus clientes bayoneses. No en vano, esas letras tenían la doble función de ser medio de pago y preciado objeto de especulación.

\section{c) Un tinte americano para la industria textil francesa: la cocbinilla}

La elevada cotización que alcanzó este tinte en el mercado francés despertó muy pronto el interés de varias firmas bayonesas, entre ellas la de la citada Barrau. Pero las trabas legales que imponía el monopolio gaditano hizo necesario entablar correspondencia con los agentes franceses radicados en los centros neurálgidos y/o puertos de llegada de ese producto a la Península, es decir, en Cádiz, La Coruña, Santander y San Sebastián. En todos ellos residían compañías francesas con las que los bayoneses pronto establecieron contactos. En Cádiz, un cuñado de Barrau fue socio de la firma "Boby, Le Gobien \& Cie», emparentada con los Boby de Rouen. Otro cuñado, llamado Taules, tuvo allí destacado a su primogénito en calidad de socio de la firma sLapetre, Taules y Cia.s, e incluso la importante compañía de los Masson, propietaria de un almacén de cochinilla en Reinosa (Santander), fue encargada por Barrau de remitir algunas partidas de cochinilla directamente a Bayona. Ese interés de los Barrau por la cochinilla obligó varias veces a la firma a enviar a algún pariente, familiar o comisionado bayonés a la ciudad de San Sebastián para pujar en las frecuen-

94 Conocemos los nombres de algunos fabricantes de la zona de Lyon que adquirieron sedas murcianas como Etienne Roustang \& Cie, Paul François Chandon, Grimond père et fils, Jean Antoine y André Martín \& Le Fort, Cauvin frères, Jean et Jacques Fornier, Angles d'Antoine, et Castagne, Samatan \& Cie y Cauvin frères. 
tes subastas que allí se hacían de este producto " $\mathrm{El}$. «elevado» número de intermediarios, en comparación a los que vimos operar para las comptas de seda y lana, muestra la dificultad que entrañaba la adquisición de un preciado tinte sujeto a los canales de distribución propios del sistema del monopolio.

La principal aspiración de estos comerciantes era asegurarse la provisión de un producto de calidad, es decir, sin mezcla de silvestre, para poder destinarlo a los cotizados mercados de Londres, Amsterdam y París. Cuando ésto no era posible, la cochinilla se enviaba a los corresponsales de Toulouse, Carcasona y Marsella, para su posterior distribución entre los metcados del Levante (Constantinopla y Reggio).

Las ventas se hacian al contado con descuentos que rondaban el $3 \%$ o bien se aplazaba el pago hasta medio año, con un interés mensual de medio punto. También existía la fórmula de pagar la mitad al contado y el resto, abonarlo en el plazo de un mes. De todas formas, colocar este producto con una cierta tentabilidad no era tarea fácil. Buena parte de las cargas expedidas a Marsella terminaron por comercializarse en la feria de Beaucaire o fueron malvendidas entre los fabricantes de Languedoc.

Otro de los aspectos que inquietaron a estos bayoneses fueron los diversos impuestos que gravaban la circulación de la cochinilla e incrementaban su precio final de venta. La conducción por tierra de Bayona a Marsella, y desde allí, a Languedoc era muy costosa. Para empezar, en la ciudad de Bayona, los comerciantes no residentes estaban obligados a abonar derechos de entrada del $3 \%$ y un potcentaje igual de salida, que se reducía al $5 \%$ cuando la operación se realizaba a cargo de la misma persona. Postetiormente, en la oficina aduaneta o ferme de Languedoc pagaban una tasa de 221 /quintal de cochinilla $\%$. No es de extrañar pues, que más de una vez, estas firmas escogiesen a pesar del riesgo la vía maritima, desde el puerto de Cádiz hasta Marsella ${ }^{97}$, donde su corresponsal remitía la cochinilla por tierra hasta su lugar de destino, en las fábricas de Carcasona.

Además de la cochinilla, otro tinte procedente del Levante español muy empleado en la industria textil francesa como blanqueador - y en las fábricas de vidrio- fue la barrilla. El trayecto desde Cartagena hasta Marsella y los sistemas de venta fueron similares a los vistos para la seda. Igualmente, los corresponsales de Marsella exigieron por su intermediación en las ventas un $2 \%$ de comisión.

95 La Compañía guipuzcoana de Caracas disponía de algunas cargas de esta mercancía. En 1740 , tuvo en su poder cincuenta lotes de tres zurrones cada uno para su venta pública. Una de las tácticas empleadas por los comerciantes bayoneses consistía en hacerse con toda la carga, pujando un precio inferior que ofrecían pagar al contado, y podía oscilar en tomo a un $10 \%$ menos al señalado por la Compañ́a.

96 En 1748 , los Roux llevaron a cabo varias gestiones para que se moderasen los derechos exigidos sobre los dieciséis fardos de cochinilla, que pensaban pasar por esta aduana.

97 En 1772, François Barrau eligió esa vía, para remitir a través del cargador gaditano A[agon et Le Fer dos barriles de cochinilla en el navío «François La Dauphine», al consignatario «Simand et fils» de Carcasona.

Hihpania, LIX/3, núm. 203 (1999) 955-987 


\section{El crédito comercial}

La clave del sistema metcantil radicaba en el crédito privado. Las dificultades inherentes a la provisión rápida de dinero era subsanado por las firmas bayonesas mediante la compra-venta de mercancías a crédito. El recurso al crédito se materializaba a través de la apertura de una cuenta corriente en las casas de banca marsellesas, que estaban vinculadas estratégicamente a las firmas francesas más sólidas establecidas en Cádiz, y en las plazas de Lyon, París y Madrid. Estos comerciantes-banqueros asumían la gestión de las ventas y el cobro de las mercancías expedidas por los Barrau, procurándoles la provisión rápida de medios de pago, en la plaza de Madrid para la compra de lanas, y en París para su provisión de telas. Los servicios bancarios y mercantiles ofertados por estos marselleses desde su estratégica plaza -receptora de piastras y conectada al centro financieto de Lyon - hacía altamente rentable la vinculación con ellos.

Cuando las lanas se vendían, a través de estos intermediarios, a los fabricantes de Languedoc, los pagos podín demorarse hasta cerca de un año, efectuándose posteriormente según los plazos cuatrimestrales de las ferias de Lyon. El comerciante distribuidor recibía en esos casos un vale, donde se indicaba el nombre del comprador-fabricante y la casa de banca en la que había domiciliado el pago, así como la cantidad a abonar y el plazo de tiempo concedido para hacerlo.

Los fabricantes languedocianos domiciliaban sus pagos en la plaza de Marsella, donde centralizaban la posterior venta de los paños fabricados con lanas españolas. Los banqueros matselleses gestionaban el cobro de los vales, percibiendo un interés, que oscilaba entre un $41 / 2$ y un 5 o $51 / 2 \%$ anual, dependiendo de la cuantía del vale. Si sucedía, aunque no era lo más frecuente, que en el momento de presentar el vale en el domicilio de pago, éste era protestado, por falta de fondos del titular o ausencia de la firma pertinente, la casa de banca cubría la irregularidad upor el honor de la firmas, reembolsándose luego mediante el giro de una letra sobre otra casa de banca, donde el deudor tuviese cuenta abierta.

El mismo mecanismo funcionaba para la comercialización de las sedas murcianas. También las casas de banca marsellesas salían garantes de las ventas a crédito efectuadas a los intermediarios de Nîmes, encargados de la distribución de este producto entre los fabricantes del lyonesado. Los pagos se estipulaban igualmente sobre las ferias de Lyon.

\section{Inversiones de capital en expediciones maritimas}

La implicación de la firma Barrau en el comercio colonial hispano-francés cubrió todas las modalidades posibles: desde los seguros martimos ${ }^{98}$, unas veces como aseguradores y otras como asegurados, pasando por la participación

98 La obra clásica sobre este tema, BorteAux, A. L., La fortune de mer. Le besoin de sécurité et les débuts de lassurance maritime, Paris 1968.

Hihpanula, LIX/3, núrn. 203 (1999) 955-987 
en armamentos vascos, el tráfico negrero, el corso y el monopolio gaditano. El capital invertido en este tipo de expediciones osciló entre las 4.000 y las 60.000 l. Es decir, haciendo gala de un espíritu inversor poco dado al riesgo, optaron por invertir pequeñas cantidades en múltiples empresas ultramatinas.

Las manufacturas enviadas al Caribe español (Campeche, Veracruz, Tabasco) o al francés (Martinica) eran aseguradas en la plaza de Marsella. Hasta tres pólizas llegaron a firmarse sobre un mismo barco. De ese modo se garantizaba el capital y la posterior llegada del producto líquido, en moneda de plata gruesa mejicana o piastras, ya que la venta se había efectuado también a crédito. Los seguros de la plaza de Marsella exigían primas que oscilaban entre el 10 y $30 \%$ del valor de la carga asegurada. La mayoría de las inversiones fueron poco rentables, bien porque los barcos naufragaron o bien porque fueron lamentablemente capturados por los corsarios ingleses. Ello dio lugar con relativa frecuencia a numerosas disputas jurídicas para el posterior cobro de los seguros, pues los diferentes y numerosos aseguradores se mostraban temisos a la hora de abonar el pago y la subsiguiente liquidación de los efectos salvados.

Además de los seguros, los bayoneses también financiaron, mediante préstamos á la grosse, en porcentajes que oscilaton el 5\% algunas expediciones guipuzcoanas, promovidas por armadores vascos, que partiendo del puerto de Pasajes se dirigían a los puertos coloniales de Veracruz y La Habana. En ellas esperaban obtener una rentabilidad entre un 90 y un $118 \%$ del capital invertido.

Y junto al Atlántico, el mar Mediterráneo. Las compañías bayonesas desarrollaron en este mar una estrategia diferente a la desplegada en el Atlántico. De asegurados pasaron a ser aseguradores. Su actuación se caracterizó por la reducida, comparativamente hablando, inversión de capital, limitándose a firmar algunos seguros que no llegaron a superar nunca la cuantía de las $2.000 \mathrm{l}$.

\section{LA COMPAÑIA DE JEAN DAGUERRE: UN EJEMPLO DE FIRMA BAYONESA ESPECIALIZADA EN LA COMERCIAIIZACION DE TEJIDOS}

Durante más de cuarenta años, entre 1764 y 1805 , este comerciante tuvo en la ciudad de Pamplona una sucursal destinada a la importación de lana y exportación de tejidos, muy similar a las de otros establecimientos organizados por sus colegas bayoneses. La filial fue regentada por varios familiares. En concreto, tenemos documentados a dos primos de Juan Daguerre y a un reducido número de factores: parientes o paisanos, como su yerno Pedro Itúrbide en Zaragoza y Santiago Darrigol, residente en Logroño. Estos empleados no eran meros testaferros, algunos llegaron a invertir una parte de su capital en la casa comercial del pariente bayonés. De la valía de este comerciante queda constancia por el hecho de que, durante la década de los ochenta, fuese elegido representante en la región de los intereses de la importante firma bayonesa, Viuda de Lalanne e bijos emparentada con Francisco Cabarrús y dedicada principalmente al tráfico de plata. Para los propósitos de nuestro estudio nos valdremos de la excepcionalidad que supone el hecho de haber localizado

Hi.ponia, LIX/3, núm. 203 (1999) 955-987 
el libro de facturas de este comerciante 99 , que cubre el período que va de 1769 a 1787, lo que facilita considerablemente el examen de su red de proveedores, a través de la cual canalizó la compra de mercancías destinadas a los mercados navarro y castellano-aragonés, así como los cambios operados en la demanda textil en esta área.

Las äreas de aprovisionamiento y la posterior distribución de textiles extranjeros en el mercado navarro

Los centros textiles europeos seleccionados por Daguerre para formar parte de su red de aprovisionamiento dan una idea de los cambios operados en la demanda, durante la segunda mitad del siglo XVIII, tanto en la región de Navarra como en los tertitorios circundantes, que son los que principalmente abasteció la firma. Observamos una evolución y diversificación del gusto, pasando de los paños de lana de calidad, procedentes mayoritariamente de Francia, a una creciente demanda de telas de lino--servilletas, camisas, lenceria-, sedas y de los nuevos tejidos de algodón, de texturas más finas y ligeras. Si hasta 1782 la mayoría de los tejidos venían de los centros textiles franceses en porcentajes que oscilaron entre el 50 y $75 \%$, a partir de 1783 fueron las regiones de Silesia y Sajonia, en Centroeuropa, las proveedoras por excelencia de la firma -cuyos tejidos exan canalizados a través de los puertos de Altona y Hamburgo-; en concreto, el mayor número de facturas tenían su origen en los centros de Hirscheberg, Schmiedeberg, Elberfeld, Bautzen y Hernhut. Cabe fijar en la coyuntura bélica de 1779 el momento de este cambio de rumbo, que además se vio favorecido por la política comercial franco-alemana, que consiguió abaratar ciertas tasas y suprimió los derechos de flete en el puerto de Hamburgo, la salida natural de la producción textil del interior alemán. Cuando las manufacturas procedian de Gran Bretaña, los puertos que concentraban el mayor volumen de exportaciones eran Leeds, Yarmouth y Londres y en el caso de Francia, Morlaix, Saint-Malo y Nantes.

Una vez que arribaban los textiles en los vecinos puertos de Bilbao, Santander, San Sebastián y Burdeos, los consignatarios franceses de Daguerre en estos puertos, el comerciante Daugirot en Bilbao y Manuel Navaz en San Sebastián, se los hacían llegar hasta Bayona, utilizando el tráfico de cabotaje. Allí se procedía a depositar los fardos en los almacenes que Daguerre tenía antes de proceder a su selección, para poder enviarlos a la sucursal de Pamplona. Durante la feria franca de San Fermín, en el mes de julio, era cuando se concentraban los mayores envios, aprovechando las exenciones aduaneras entonces vigentes. Siguiendo el curso fluvial del río Nîve se cubría el trayecto de Bayona hasta los almacenes situados en las localidades fronterizas de Ustáriz, Cambó y Ainhoa donde se localizaban las fermes $u$ oficinas de aduanas. Desde allí los trajineros conducían las cargas hasta el establecimiento de Pamplona, que funcio-

99 ACCIB. Registro de facturas de Jean Daguerre d'Ospital VE 1/1 (1769-1787). 
naba como lugar central de venta, local y almacén para la distribución de manufacturas entre los minoristas de las localidades navartas y las castellanas de Soria, Sigüenza, Enciso, Agreda y Almazán. Pero también eran numerosos los pequeños comerciantes de localidades navarras que se desplazaban expresamente a Pamplona pata efectuar alli sus compras, durante el tiempo de feria y después se encargaban de su reventa. Daguerre también dispuso de proveedores en la zona de Olorón y Labastida-Clairence (Bearne) de donde se surtía de los tejidos de lana más burdos y de aquellos otros de lino que tenían gran demanda entre amplios sectores de la sociedad navarra.

El propósito que ha guiado este trabajo no ha sido tanto hacer un estudio de la inmigración bayonesa a España, empresa de indudable complejidad, ni un análisis detallado de su sector mercantil, como el de subrayar la importancia que la villa fronteriza de Bayona y los comerciantes procedentes de dicha ciudad portuaria y su entorno, incluyendo la región de Bearne, _-situadas ambas en el Pirineo occidental-, ejercieron sobre determinadas áreas de la geografía mercantil española. Aquellas que durante el Setecientos presentaron un mayor dinamismo como el Levante, la región de Murcia, el triángulo formado por Cádiz-Sevilla y Málaga, la cornisa cantábrica y Aragón. La atención se ha fijado especialmente en un espacio interregional escasamente atendido por la historiografia, a pesar de reunir la peculiaridad de ser el paso terrestre más corto que comunicaba el gran centro de consumo de Madrid con la frontera francesa. Nos referimos a Navarra y a las regiones situadas en su límite metidional, es decir, en el área comprendida por los actuales regiones de Soria, La Rioja y la parte suroccidental de Aragón.

En este espacio interregional y fronterizo los inmigrantes bayoneses y bearneses encontraron un campo abonado para la actividad comercial, debido sin duda a las ventajas fiscales que proporcionaba la existencia de una frontera económica situada no en los Pirineos sino en el cordón aduanero del Ebro. Una frontera con la que la monarquía española mantendrían una actitud tolerante aunque progresivamente fuese imponiendo un mayor control comercial. Buena parte de los más significativos de esos comerciantes extranjeros eran agentes de firmas bayonesas cuya sede social radicaba al otro lado de la frontera, en calidad de factores, empleados o socios. Esas casas cometciales bayonesas que tenían sucursales en Pamplona regentadas por algún pariente o paisano tejieron redes que les ligaban a los centros mercantiles más importantes de la geografía española, y a éstos con el mercado francés y europeo. Esas redes comerciales penetraban a diferente escala en el ámbito local, regional, interregional, nacional e incluso internacional.

Pero la participación francesa, aún siendo importante, habida cuenta la complementariedad existente entre las ventajas fiscales de Navarra y del País Vasco-francés, tuvo su principal razón en unos intercambios basados en el tráfico lanar de exportación, en los productos coloniales, textiles y otras manufac-

Hitpania, LIX/3, núm 203 (1999) 955-987 
turas orientados a la importación, pero sobre todo en el tráfico legal e ilegal de la plata americana, implicándose apenas en la comercialización de los excedentes agrarios (cereales y vino) de la región. Hay que tener presente que Bayona fue en ese siglo uno de los principales centros franceses de acuñación de moneda y redistribuidor de plata amonedada en el mercado europeo, en parte gracias a las conexiones de la élite judía bayonesa del burgo del Santo Espíritu con sus correligionarios de Amsterdam, Londres y Burdeos, así como por las facilidades que encontraron esos bayoneses para canalizar vía terrestre y marítima el transporte de numerario desde los puertos vascos y los pasos fronterizos del Pirineo hasta Bayona y de allí, a través de Toulouse, a la plaza marsellesa.

Especialmente conviene resaltar cómo por debajo de esa circulación de mercancías y numerario se entrevé la capacidad de esos inmigrantes para estrechar relaciones comerciales transfronterizas basándose en la configuración de unas redes de parentesco y de paisanaje, que les ligaban a sus compatriotas situados en otras áreas españolas. Este tejido mercantil conservó su solidez gracias a la continua incorporación y promoción de nuevos inmigrantes a las compañías y establecimientos que sus homólogos tenían en España. No obstante, esas redes foráneas aunque consiguieron controlar el comercio exterior con Francia, en este espacio próximo a la frontera pirenaica, no lograron hacerse con la completa tutela sobre los sistemas de distribución tegional e interregional, lo que se manifiesta por la existencia de unas redes conmerciales autóctonas desligadas de la tutela bayonesa. 